\title{
Environmental Racism Discourse and Indigenous Peoples
}

\author{
By: R. Lloyd Gamble, MSc., BSc
}

\author{
A thesis submitted to \\ the Faculty of Graduate Studies and Research \\ in partial fulfilment of \\ the requirements for the degree of
}

\author{
Masters of Arts
}

Department of Legal Studies

Carleton University

Ottawa, Ontario

(C) December 2005, R. Lloyd Gamble 


$\begin{array}{ll}\begin{array}{l}\text { Library and } \\ \text { Archives Canada }\end{array} & \begin{array}{l}\text { Bibliothèque et } \\ \text { Archives Canada }\end{array} \\ \begin{array}{l}\text { Published Heritage } \\ \text { Branch }\end{array} & \begin{array}{l}\text { Direction du } \\ \text { Patrimoine de l'édition }\end{array} \\ \begin{array}{l}\text { 395 Wellington Street } \\ \text { Ottawa ON K1A ON4 }\end{array} & \begin{array}{l}\text { 395, rue Wellington } \\ \text { Ottawa ON K1A ON4 } \\ \text { Canada }\end{array}\end{array}$

Your file Votre référence

ISBN: 0-494-13414-3

Ourfile Notre référence

ISBN: 0-494-13414-3

NOTICE:

The author has granted a nonexclusive license allowing Library and Archives Canada to reproduce, publish, archive, preserve, conserve, communicate to the public by telecommunication or on the Internet, loan, distribute and sell theses worldwide, for commercial or noncommercial purposes, in microform, paper, electronic and/or any other formats.

The author retains copyright ownership and moral rights in this thesis. Neither the thesis nor substantial extracts from it may be printed or otherwise reproduced without the author's permission.
AVIS:

L'auteur a accordé une licence non exclusive permettant à la Bibliothèque et Archives Canada de reproduire, publier, archiver, sauvegarder, conserver, transmettre au public par télécommunication ou par l'Internet, prêter, distribuer et vendre des thèses partout dans le monde, à des fins commerciales ou autres, sur support microforme, papier, électronique et/ou autres formats.

L'auteur conserve la propriété du droit d'auteur et des droits moraux qui protège cette thèse. $\mathrm{Ni}$ la thèse ni des extraits substantiels de celle-ci ne doivent être imprimés ou autrement reproduits sans son autorisation.
In compliance with the Canadian

Privacy Act some supporting forms may have been removed from this thesis.

While these forms may be included in the document page count, their removal does not represent any loss of content from the thesis.
Conformément à la loi canadienne sur la protection de la vie privée, quelques formulaires secondaires ont été enlevés de cette thèse.

Bien que ces formulaires aient inclus dans la pagination, il n'y aura aucun contenu manquant.

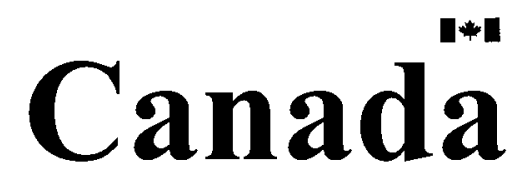




\begin{abstract}
This thesis argues that the environmental policies and processes of the Canadian state have adversely affected the sustainability of Aboriginal societies and are racist. An expanded concept of environmental racism is developed to analyze this circumstance since current environmental justice theory has concentrated on civil rights discourse or ethnic minority rights, ignoring Aboriginal human rights as peoples/nations. The adverse environmental impacts borne by First Nations must be considered from a human rights perspective since they are both 'legally' and morally entitled to groups rights as original peoples and to the individual rights generally associated with civil rights provisions. The concept of environmental racism, and its accompanying analytic, are expanded by taking into account sociological and biophysical factors affecting the human right to security of person and the right of self-determination. These are operationalized by: examining the loss of First Nations lands as necessary means of subsistence; analyzing systemic racism in legislation and process that excludes First Nations; detailing the toxic racism associated with exploitive resource development; and affirming tribal sovereignty as a means for resisting environmental displacement and degradation. The environmental racism faced by Indigenous peoples in Canada is argued to be neocolonialist in nature since producing the 'colonialist' effects of destruction and displacement by 'toxic' means, rather than through direct violence. I argue that the assertion and affirmation of First Nation sovereignty may facilitate redressing the environmental racism they face.
\end{abstract}




\section{Acknowledgments}

I wish to express my sincere gratitude to Dr. Peter Swan, my research supervisor, for his generous help, guidance and support throughout the course of this work.

I would also like to express my gratitude to the members of my family and all my friends for the ongoing care and warmth which they have offered me over the years. Finally, this thesis would not have started and reached an end, if I had not the good fortune to have a loving spouse, Mary-Lynn, loving parents and two wonderful sons, Tyrone and Rory.

Finally, I would like to thank Merv Fingas and Carl Brown who were supportive of this endeavour. 


\section{Preface}

IN THE TIME BEFORE there were human beings on Earth, the Creator called a great meeting of the Animal People. During that period of the world's history, the Animal People lived harmoniously with one another and could speak to the Creator with one mind. They were very curious about the reason for the gathering. When they had all assembled together, the Creator spoke.

"I am sending a strange new creature to live among you," he told the Animal People. "He is to be called Man and he is to be your brother. But unlike you he will have no fur on his body, will walk on two legs and will not be able to speak with you. Because of this he will need your help in order to survive and become who I am creating him to be. You will need to be more than brothers and sisters, you will need to be his teachers.

"Man will not be like you. He will not come into the world like you. He will not be born knowing and understanding who and what he is. He will have to search for that. And it is in the search that he will find himself.

"He will also have a tremendous gift that you do not have. He will have the ability to dream. With this ability he will be able to invent great things and because of this he will move further and further away from you and will need your help even more when this happens.

"But to help him I am going to send him out into the world with one very special gift. I am going to give him the gift of the knowledge of Truth and Justice. But like his identity it must be a search, because if he finds this knowledge too easily he will take it for granted. So I am going to hide it and I need your help to find a good hiding-place. That is why I have called you here."

A great murmur ran through the crowd of Animal People. They were excited at the prospect of welcoming a new creature into the world and they were honoured by the Creator's request for their help. This was truly an important day. One by one the Animal People came forward with suggestions of where the Creator should hide the gift of knowledge of Truth and Justice.

"Give it to me, my Creator," said the Buffalo, "and I will carry it on my hump to the very centre of the plains and bury it there."

"A good idea, my brother," the Creator said, "but it is destined that Man should cover most of the world and he would find it there too easily and take it for granted."

"Then give it to me," said the Salmon, "and I will carry it in my mouth to the deepest part of the ocean and I will hide it there."

"Another excellent idea," said the Creator, "but it is destined that with his power to dream, Man will invent a device that will carry him there and he would find it too easily and take it for granted."

"Then I will take it," said the Eagle, "and carry it in my talons and fly to the very face of the Moon and hide it there."

"No, my brother," said the Creator, "even there he would find it too easily because Man will one day travel there as well." 
Animal after animal came forward with marvellous suggestions on where to hide this precious gift, and one by one the Creator turned down their ideas. Finally, just when discouragement was about to invade their circle, a tiny voice spoke from the back of the gathering. The Animal People were all surprised to find that the voice belonged to the Mole. The Mole was a small creature who spent his life tunnelling through the earth and because of this had lost most of the use of his eyes. Yet because he was always in touch with Mother Earth, the Mole had developed true spiritual insight. The Animal People listened respectfully when Mole began to speak.

"I know where to hide it, my Creator," he said. "I know where to hide the gift of the knowledge of Truth and Justice."

"Where then, my brother?" asked the Creator. "Where should I hide this gift?"

"Put it inside them," said the Mole. "Put it inside them because then only the wisest and purest of heart will have the courage to look there."

And that is where the Creator placed the gift of the knowledge of Truth and Justice. $^{I}$

${ }^{1}$. Based on a story by Phil Lane, Jr., Four Worlds Development, University of Lethbridge, Lethbridge, Alberta, as retold by Richard Wagamese. 


\section{Table of Contents}

$\begin{array}{ll}\text { Abstract } & \text { ii }\end{array}$

$\begin{array}{ll}\text { Acknowledgments } & \text { ii }\end{array}$

Preface iv

Table of Contents vi

List of Figures ix

1 Introduction 1

Introduction $\quad 1$

Environmental Racism: The Emergence of the Concept 1

Research Question $\quad 5$

Hypothesis 6

$\begin{array}{ll}\text { Outline of Remainder } & 7\end{array}$

2 Theoretical and Methodological Framework 9

Introduction 9

Theorizing Race and Environmental Justice Discourse 10

Environmental Racism: Critically Examining the Concept 11

Reformulating the Concept of Environmental Racism:

Broadening the View 13

Environmental Racism and Human Rights $\quad 14$

Environmental Racism and Toxic Racism 18

Environmental Racism, Governance and Sovereignty 20

De- and Reterritorialization: Sovereignty as a Challenge

to the Western Property Rights Regime 27

Consequences of Environmental Racism: Neocolonialism, Uneven Geographies of Poverty and Sustainable Development 28

Possibilities for Change: From Subordination to Antagonism 29

Methodology and Analysis 31

Figure $1+33$

$3 \quad$ Patterns of Systemic Racism in Legislation and Process 34

Introduction 34

The Canadian Environmental Assessment Act (CEAA):

vi 
CEAA Legislation and Process as a Contravention

of Human Rights

Flawed Legislative Process and Systemic Racism

in the Fisheries

Systemic Racism and the Department of Fisheries

and Oceans (DFO)

The Collapse of the Fishery $\quad 50$

Discussion 51

Conclusion $\quad 53$

4 Four Facets of Toxic Racism: Food Contamination, Ecosystem Health, Noise Pollution and

Electromagnetic Radiation

Introduction: Toxic Racism and Macro-Impacts

The Current Governmental Context

and 'Externalities'

Food Chain Contamination

Uranium Mining and Food Chain Contamination 62

Mercury Poisoning in Northern Ontario 66

PCB Incineration at Swan Hills Alberta 66

Pulp and Paper Contamination of Water

in Northern Alberta and the N.W.T.

Ecosystem Health, Habitat Loss and Overexploitation in Pulp and Paper and Hydroelectric Production

Noise Pollution: Military Low-Flying in Quebec

and Labrador

Electromagnetic Radiation from

High Voltage Transmission Lines $\quad 78$

The Mortifying Effects of Toxic Racism $\quad 79$

The State, Economic Development and Toxic Racism 81

$\begin{array}{ll}\text { Toxic Contaminants and Risk } & 87\end{array}$

$\begin{array}{ll}\text { Conclusion } & 89\end{array}$

5 Aboriginal Sovereignty and Environmental

Racism Discourse

$\begin{array}{ll}\text { Introduction } & 92\end{array}$

Analytical Context $\quad 94$

First Nations and Sovereignty: The Canadian Pattern 95

Human Rights, Self-Determination and Sovereignty 96 
Treaties, First Nations Sovereignty

and the Canadian State

Resource Development and the Unconstitutional Actions

of the Canadian State

Sovereignty as a Potential Strategy

Conclusion

$6 \quad$ Conclusion

Bibliography 


\section{List of Figures}

Figure 1: This figure depicts development activities that can be construed as exhibiting elements of environmental racism. Qualitative and quantitative data given in the text and accompanying footnotes provide proof of environmental racism towards Indigenous peoples. 


\section{Chapter 1: Introduction}

\section{Introduction}

This thesis is concerned with developing an expanded concept of 'environmental racism' by incorporating human rights discourse, especially with regards to systemic racism in state legislation and process, toxic racism and sovereignty. These approaches allow us to grasp how the Canadian state is complicit in a form of neocolonialism, producing effects of displacement and environmental degradation to which Indigenous peoples are subjected. My expanded environmental racism discourse is used to critically analyse particular cases of environmental policy development in the Canadian context.

\section{Environmental Racism: The Emergence of the Concept}

'Environmental racism' as a concept was first introduced by Dorothy Nelkin in 1981 as 'toxic racism' after conducting a survey of environmental liabilities located on Indian lands in the United States. However, until the term 'environmental racism' was adopted by the U.S. civil rights movement (Bullard, 1993; 1994) as an infringement on minority rights, Nelkin's findings for Indigenous peoples were largely overlooked or ignored. Recently, this phenomena is more often discussed in terms of "environmental justice' rather than environmental racism (Kuehn, 2000).

Environmental justice is a term that means many things to many people (Kuehn, 2000). This has resulted in confusion concerning what 'environmental justice' entails. Generally, the concept of environmental justice has been applied to any group 
experiencing a disproportionate amount of environmental risks and burdens stemming from prejudice or bias from a range of factors: intra- and inter-generational (Buttel \& Flinn, 1978; Rees, 1991; Hornstein, 1992; Maggio, 1997; Attfield, 1998, and Perera et al., 1999), age (Stephens, 1996), race and ethnicity (Rex, 1986 and Burke, 1993), class (Cole, 1992; McMaster et al., 1997, and Walker, 1998), gender (Collins, 1994, and Davidson and Freudenburg, 1996) and geopolitical (Cutter et al., 1996). These factors, more often than not, involve those who already are the most socially, politically and economically vulnerable within society.

Kuehn (2000) contends that environmental justice as a concept lacks clarity and fails to capture the essence and breadth of the different types of environmental justice and proposes a taxonomic approach. However, within this scheme, there are no provisions for ranking various levels of injustice. By incorporating a rights-based model and adopting a Darwinian ecologistic approach as I propose, 'environmental racism' becomes a key component of environmental justice deserving analysis in its own right . Within this theoretical framework, racial discourse becomes key to understanding environmental injustices visited upon Indigenous peoples and "Peoples of Colour" as a result of environmental human and civil right violations. These violations can be profiled, quantified and weighted accordingly. The remaining classes, intra- and inter-generational, age, gender, class, geopolitical and ethnicity, perhaps might be captured within a defined secondary class, determined more by bias than prejudice.

However, referring to matters of racism and the environment solely in terms of environmental justice rather than environmental racism tends to obscure racist nuances 
and the nature of systemic violence experienced by Indigenous peoples and 'Peoples of Colour.' The concept of 'environmental racism' more adequately accounts for the "racist perceptual schemas of national, ethnic and social difference" (Balibar, 1991), thus capturing the core elements of Aboriginal environmental justice claims. For this reason I have chosen to advance Aboriginal claims using 'environmental racism' rather than only using the current 'environmental justice' analytic.

Why broach the subject of environmental racism when sovereignty and land rights would seem to be the more appropriate venue for tackling Indigenous rights? Sovereignty is a construct of statist discourse which in turn, attempts to justify the control, use and enjoyment of land within territories falling under the sovereign domination of a particular state. States have frequently rationalized their existence through discursive formulations that often treat 'sovereignty' as a sacrosanct principle of its legitimations. When negotiations pertaining to state authority and land use occur between Indigenous peoples and states, it is frequently the state that sets or controls the agenda, thus attempting to dominate Indigenous peoples by arrogating sovereignty to itself. Environmental racism discourse offers a means to subject statist discourse and practice to both internal scrutiny (e.g., public perceptions of fairness) and external scrutiny (e.g., international human rights). This could foster democratic dialogue on shared sovereignty and the re-territorialization of Indigenous lands. This could also possibly lead to the reformulation of state doctrines. So, the reason for starting with the subject of environmental racism is because this discourse integrates environmental values with human rights. By adopting a rights-based strategy or social advocacy, environmental 
racism discourse helps unmask salient forms of domination and exploitation (Larrain, 1994).

Using the concept of environmental racism produces knowledge that can potentially shape the perceptions and practices of social analysts and political actors. Thus, I contend that the notion of environmental racism can advance our awareness of the vulnerability of Indigenous peoples to the subtleties and insidious effects of cultural imperialism, especially environmental displacement of Indigenous peoples.

Environmental racism discourse thus aims for a broader, more inclusive view of the position of Indigenous peoples, incorporating economic, political and social forces that influence discriminatory practices into its analyses.

Moreover, I expand the concept of environmental racism by linking it to patterns of systemic racism in Canadian legislation and process and two central tenets of human rights discourse: security of person and self-determination. Toxic racism, as a facet of environmental racism, is linked to 'security of person' since toxics in the food chain and in the water supply, for instance, contradicts the right of security of person. And last, the matter of sovereignty and the question of environmental racism, is linked with the right to self-determination. Integrating human rights discourse into an expanded notion of environmental racism thus also provides a different way of incorporating questions of environmental justice, thus forming a broader, more inclusive framework for handling questions of justice and the environment.

My intention is to help widen the environmental political agenda, and at the same time broaden the perspective on, and legitimacy of, Aboriginal environmental claims. 
Below, the socio-cultural context of environmental practices impacting on Aboriginal communities, will be examined in order to confront issues of environmental racism, critically analyzing currently held 'truths' of the state, namely, that Canada is a just and fair society. I argue that analyzing issues pertaining to Aboriginal claims and the environment from the point of view of environmental racism will enhance the legitimacy and scope of Aboriginal claims to social and political justice. A new (or renewed) relationship between Aboriginal peoples and states can be achieved only through the awareness of past mistakes and the future avoidance of the false and unwarranted assumptions that led to current discriminatory practices and their harmful effects.

\section{Research Question}

Environmental racism has proven to be both a powerful theoretical and practical tool in unmasking environmental inequity endured by ethnic minorities in the United States. However, little or no attempt has been made to address environmental racism as it pertains to Indigenous 'Peoples' across North America. So, the questions orienting this thesis are: 'How are environmental burdens different for Indigenous peoples and do these contribute to the racial subordination and oppression of Aboriginal communities in the recent Canadian context?' and 'Would exposing the socially embedded character of racial subordination and oppression of Aboriginal environmental issues provide another tactic for advancing Indigenous rights and provide a new forum for resistance?' 


\section{Hypothesis}

The perception of Canada as a fair and just society continues to prevail. But this explicit ideology is contradicted by policies, legislation, institutions and practices that are rooted in neo-colonial, racist attitudes and practices toward Indigenous peoples. Both colonialist and neocolonialist practices attempt to displace populations, hence clearing an area to be colonized. Under neocolonialism, environmental destruction and degradation produce the same effect of population displacement. This clears an area that is frequently developed by corporations to the benefit of those corporations and to Federal and Provincial governments. These practices are racist in that they actively, purposely and effectively exclude Indigenous peoples from decision-making processes. Indigenous peoples are then left to manage the adverse effects of these decisions. The effects, of which, Indigenous peoples must then manage. At the same time, the state arrogates the claim of legitimacy to itself. This has severe repercussions for environmental legislation and Aboriginal human rights. Environmental racism discourse offers a perspective that integrates environmental values into human rights discourse thus helping to unmask links between racism and environmental quality. This produces knowledge that could shape public perception and institutional practice. Potentially, this form of critical knowledge could focus national and international attention on environmental inequities and racism concretely faced by Indigenous peoples, perhaps advancing the cause of social and environmental justice. 


\section{Outline of Remainder}

My expanded concept of environmental racism is put to work in the remaining five chapters. In the next chapter, I elaborate on my critique and reformulation of environmental racism, that is, expanded by integrating it with human rights discourse, toxic racism and the problem of sovereignty. I then outline my methodology. In Chapter 3, I analyse patterns of systemic racism in legislation and process, focussing primarily on the Canadian Environmental Assessment Act (CEAA). This is linked with the discourse of 'sustainable development'. I pay close attention to environmental liabilities in the East and West coast fishery as a result of flawed legislative processes. Chapter 4 addresses toxic racism as it applies to First Nations in Canada taking account of the pulp and paper industry and uranium mining. Toxic racism is defined as a subset of environmental racism. I address the macro-impacts or external pressures of toxic racism associated with resource extraction and environmental degradation on a massive scale. Chapter 5 speaks to Indigenous sovereignty within the context of the Canadian state and the over-coding of state prerogative, which has lead to environmental racism. The final chapter, Chapter 6 summarises the findings of the thesis and concludes.

My aim in this thesis is to highlight the extent to which Aboriginal peoples in Canada have been and continue to be subjected to forms of environmental racism. I do so by developing the concept of environmental racism through both critical assessment and empirical research by casting light upon the environmental and physical harm and neocolonialist displacement caused by environmental degradation and how both impact on the politics of sovereignty. In pursuing this line of research, I aim to highlight the 
extent to which Aboriginal peoples in Canada have been and continue to be subjected to forms of environmental racism.

Throughout this work, I remain sensitive to the cautions articulated by Cameron and White (1995) that it is wrong to assume that Aboriginal peoples adhere to a single political agenda or exhibit identical cultures and lifestyles. Hence, the political objective with which this project is allied concerns de-colonization and the dispersal of sovereignty. I thus suggest that if Indigenous peoples were to rightly achieve control over essential resources, racial subordination and domination should subside. 


\section{Chapter 2: Theoretical and Methodological Framework}

\section{Introduction}

The central term of this thesis is the expanded concept of environmental racism. In this chapter, I explicate the theoretical and methodological framework necessary to understanding my expanded concept of 'environmental racism' and lay out my underlying assumptions. This indicates how my analytic, based on this concept, is later put to work to account for environmental racism in the Canadian context. The entry point is my critique and reformulation of the concept of environmental racism. Broadening the framework of environmental racism allows one to incorporate matters of environmental justice, human rights, toxic racism and sovereignty. In doing so, I show how this can supplement analyses that focus on 'environmental justice'. My aim is to provide the analytical and methodological tools for a more comprehensive approach able to integrate matters of justice, rights, the environment and social, economic and cultural factors. These shape both the struggles over the environment and the struggles against neocolonialist effects faced by Aboriginals. The expanded concept of environmental racism thus provides, I contend, a more comprehensive tool for analyzing, explaining and potentially resisting the racist effects of environmental degradation that result in neocolonialism, i.e., colonialism by other means. My immediate concern here is to define my key concepts and their connections subtending my analyses and accounts of environmental racism.

Framing the thesis in terms of environmental racism changes the way 
environmental injustices faced by Indigenous peoples and the subsequent social consequences, are viewed. This makes environmental racism discourse both powerful, and culturally resonant (cf. Capek, 1993). Framing the question as both an environmental and social justice issue has the ability to expose the racist underpinnings of 'neocolonialist' actions that produce environmental and social stratification. This interpretive frame, environmental racism discourse, serves both to conceptually clarify the stakes in environmental justice, while acting as a rallying point from which one can mobilize Indigenous, popular and academic discourses toward a shared goal of environmental justice for First Nations. The political implications of this are that neocolonialist injustices, perpetrated by state institutions, can be challenged on a variety of fronts by a variety of actors. Environmental racism discourse accentuates environmental racism claims by questioning and challenging systemic inequalities and structural obstacles based on race and the distribution of power.

\section{Theorizing Race and Environmental Justice Discourse}

The discourse of environmental justice seeks to forge a link between social justice and environmental quality. However, for environmental justice to reflect Indigenous environmental issues, it must incorporate some conception of racism and include human rights more fully into the environmental justice paradigm. Racism, in its many forms, pervades society, including areas concerned with environmental protection (Northridge and Sheppard, 1997). The question of racism in contemporary political culture is highly charged and laden with meaning (Fields, 1990). At core, I take racism to mean 'racial 
prejudice plus power'. This is in line with the definition offered by Gareis-Smith for whom racism refers to the "intentional and unintentional use of power to isolate, separate and exploit others" $(1994,59$; cf. Torres, 1992). Thus, racism is more than just a personal attitude; it also refers to the institutional crystallizations facilitating and perpetuating such attitudes.

'Racism', although a broad term, is frequently linked with concerns over human rights, and procedural and distributive justice issues. As I show below, the environmental racism toward Aboriginals perpetrated by the Canadian state has three characteristic features. First, it involves physical displacement as a result of development activities without due process or compensation. Second, it results in habitat destruction and degradation. And last, the effects of racism lead to compromised environmental sustainability, environmental productivity and diminished environmental quality. This synthesis of horizons (Tribes, 1989) between Indigenous environmental concerns and those of racial injustice, provides a more coherent, substantive perspective on environmental justice and potentially, conceptual innovation (cf. Nielsen et al., 1990; Foster, 1993).

\section{Environmental Racism: Critically Examining the Concept}

Environmental racism together with environmental justice have great potential for providing powerful theoretical and practical tools when addressing environmental injustices. However, the conceptual tools and political goals of environmental justice, and its potential links with racism, have not been well delineated and hence are often 
conceptually inaccessible. For example, when it came to minority claims of environmental racism, the American civil rights movement began by focussing research on environmental civil rights violations. Indigenous peoples' claims however, go beyond 'the state' since Indigenous peoples would argue that their environmental human rights as peoples/nations are being violated.

Since Indigenous environmental claims have not been studied in detail, environmental racism discourse is lacking in it. By restricting its analyses and concerns to those of specific minorities, e.g. ethnicity, conventional 'civil rights' concerns with racism, and the environment and justice have undermined its own laudable ideal of more radical environmental and legal transformation. This is because it has a politically limiting and narrow definition (Redpole, 1992; Pulido, 1996). These concepts need to be broadened to include Indigenous environmental issues, recognizing inherent differences in pattern and scale (i.e. qualitative difference) at both the environmental and sociological levels. This is not to say that earlier concepts of environmental justice were wrong; rather, they were incomplete. Thus, unlike 'people of colour'/visible minorities, on which earlier theories of environmental racism were conceptualized (Bullard, 1983; 1993; 1994), there is a direct (versus indirect) correlation between environmental degradation, physical displacement, and cultural and physical well-being for Aboriginal communities. Indigenous peoples view the environmental depredations visited on them as merely one more manifestation of colonialism. If environmental racism discourse is to be salient, it must target and combine Indigenous concerns over social justice with environmental and human rights issues. 


\section{Reformulating the Concept of Environmental Racism: Broadening the View}

Some environmental justice researchers contend that environmental racism, as it applies to First Nations, is self-evident. However, to date, this topic has received only cursory treatment in academic, social and political circles both within and without the United States (Bullard, 1994 and Di Chiro, 1995). In Canada, we also remain ignorant of Indigenous peoples' claims--in particular, the nature, depth and extent of the environmental oppression (Redpole, 1992). Environmental justice discourse requires a framework that retains a broader view of economic, political and social forces and their interactions affecting various cultural landscapes and institutions. Thus, environmental justice discourse must acknowledge the institutionalization of unconscious biases, exclusionary processes and normative judgments that influence racially meaningful social structures (Foster, 1993). Torres (1992) labels any environmental practice as environmental racism if "the predictable distributional impacts of that decision contributes to the structure of racial subordination and domination" (page 840). This definition facilitates grasping the structural and institutional nature of environmental racism and provides greater flexibility and manoeuverability for analyzing Aboriginal environmental justice issues, including sovereignty.

Simply put, environmental racism reveals an institutional racism running much deeper than prejudice. In this light, part of the analytical challenge involves understanding how environmental racism operates in conjunction with a particular political-economic system that "fails to recognize or acknowledge that protecting environmental values is anterior to and a prerequisite for protecting all our other core human rights." (Williams, 
1994). With the inclusion of race as a variable, one can reveal the socially-embedded and value-laden political character of environmental racism and expose discriminatory environmental outcomes.

\section{Environmental Racism and Human Rights}

For Aboriginal peoples, environmental racism has received comparatively little attention (Nelkin, 1981 and Pinderhughes, 1996). The definition of 'environmental racism' is in harmony with the broader native issues of 'inherent' rights as original peoples. Legal rights, property rights and cultural identity are implicit in their "inherent rights'. Indigenous Nations have inherent rights as 'peoples', i.e. collective human rights that are distinct from ethnic/minority rights. Thus, expanding the concept of environmental racism by including human rights discourse allows for a more coherent and comprehensive analytic, a more adequate methodological tool for making sense of the complexities of politics, racism and the environment as concerns First Nations and the Canadian state. This also means considering the politics of collectivities.

According to the Universal Declaration of Human Rights Article 3: 'Everyone has the right to life, liberty and security of person', and Article 17 reads: (1) 'Everyone has the right to own property alone as well as in association with others' and (2) 'No one shall be arbitrarily deprived of his property'. Similarly, the International Covenant on Economic, Social and Cultural Rights, Article 25 and Universal Declaration on Rights of Indigenous people provides for the right of self-determination for 'peoples'. An interference is usually considered to be an intervention that affects the integrity or 
physical well-being of a person, that is foreseeable and of a serious and irreparable nature. For example, human rights are abused when political and economic institutions and processes wrest control over traditionally held resources from Indigenous 'peoples' without negotiation or compensation.

The environmental racism faced by First Nations can also be construed as a form of apartheid. The International Convention on the Suppression and Punishment of the Crime of Apartheid, Article II, defines 'apartheid' as:

-the denial to a member or members of a racial group or groups of the right to life and liberty of person by inflicting upon the members of a racial group or groups of serious bodily or mental harm, by infringement of their freedom or dignity, or by subjecting them to torture or to cruel, inhuman or degrading treatment or punishment;

-deliberate imposition on a racial group or groups of living conditions calculated to cause its or their physical destruction in whole or in part;

- any legislative measures and other measures calculated to prevent a racial group or groups from participation in the political, social, economic and cultural life of the country and the deliberate creation of conditions preventing the full development of such a group or groups, in particular by denying to members of a racial group or groups basic human rights and freedoms;

- any measures including legislative measures, designed to divide the population along racial lines by the creation of separate reserves and ghettos for the members of a racial group or groups, the prohibition of mixed marriages among members of various racial groups, the expropriation of landed property belonging to a racial group or groups or to members.

Human rights also speak to the right to: a safe environment; political participation;

freedom from violence; due process of law; education; and adequate nutrition.

International human rights have increasingly put a lot of emphasis on the rule of law and due process (http://www.un.org/Overview/rights.html). 
Environmental racism as it applies to colonized 'peoples' is particularly insidious since both environmental racism and colonialism operate according to similar antagonisms and exclusions (cf. Young, 1993). Native populations that have been subjugated in the past--and, some would argue, the present--through apartheid and genocide (Taliman, 1992) are now being exposed to a more subtle form of cultural suppression. Thinking about environmental racism as 'genocidal' elucidates the stakes in the matter.

The definition of 'genocide' is enshrined in Article 2 of the Convention on the Prevention and Punishment of the Crime of Genocide. The Convention defines genocide as "act committed with intent to destroy, in whole or in part, a national, ethnic, racial or religious group," for example, causing serious bodily or mental harm to members of the group. Taliman (1992) argues genocide against Native Peoples has been perpetuated through both covert and overt means. As I demonstrate through a number of cases, in the recent Canadian context, a strong case can be made that the environmental racism faced by First Nations amounts to a breach of their human rights.

Highlighting the human rights to security of property, security of person and collective self-determination thus brings to the fore the extent to which the Canadian state has historically disregarded these rights. Also, these three rights can be fruitfully linked with the flawed legislative process, toxicity and sovereignty respectively. That is to say that human rights discourse focuses our attention on the extent to which the environmental racism faced by Aboriginals in Canada are breaches of these rights and have more than a little in common with apartheid, genocide and neocolonialism. 
However, there is an inherent tension, both in my own and in First Nations', deployment of a Euro-centrist human rights discourse to ground non-Eurocentric rights claims. These tensions make their presence felt in analytical, normative and strategic terms. But, this circumstance, itself, is a consequence of how 'Aboriginals' are positioned in relation to the Canadian state. So, analytically on the one hand they are 'inside' of it, and on the other 'outside' of it. They are 'inside' of the Canadian state arena where Eurocentrist human rights discourse functions as one possible resource of claims legitimacy, since Aboriginals are charges of the Crown according to acts of the Canadian Constitution (1967 and 1982). They are also 'outside' of the Canadian state because of the minimally tacit supposition of the sovereignty of First Nations since treaties, which can only be obtained between sovereign peoples according to the modern international state systems, exist between First Nations and the Canadian state. There is also a 'third' position Aboriginals occupy and this is their position of 'autonomy', i.e., the ways in which they relate to themselves in and through the normative conceptions of their respective communities. Thus, in certain contexts, it is analytically useful to think about environmental racism in terms of 'human rights' since this notion is at play in the arena of Canadian state legislation and process. In normative terms, things become more problematic since I do not wish to impose or assume a Euro-centric normative model on First Nations normative frameworks or approaches. Indeed, such an imposition would risk repeating a form of colonialism in this very work. Last, and in my view, most importantly, is the strategic dimension of First Nations use of human rights discourse. In this regard, it is necessary to keep in mind the complexities of the triple-positioning of 
Aboriginal peoples. It is useful to think about First Nations own use of human rights discourse, and my own use of human rights discourse as a tactical instrument amongst others, which need not be wholly adopted or affirmed. Rather, it is deployed, herein in the interest of increasing and achieving substantive autonomy and means of selfdetermination.

\section{Environmental Racism and Toxic Racism}

The second component of an expanded conception of environmental racism involves incorporating the concept of 'toxic racism'. ${ }^{2}$ Including this concept in the analytic of the expanded concept of environmental racism, helps to focus our attention on the effects of environmental degradation in the broader ecosystem, and its consequent adverse sociological effects, even if these occur independently of people's awareness of them. Nelkin (1981) developed the concept to capture the environmental degradation and habitat destruction found on American Indian reservations, attributable to multinational corporations and federal agencies.

Toxic racism refers to the immense geography of scale impairing critical ecosystem components and environmental health, as well as Indigenous social, cultural and economic well-being. As such, the concept takes account of four main areas: contamination of the food chain; ecosystem health; noise pollution; and electromagnetic radiation. The sense in which I use the concept here requires focussing on 'macro-

2. 'Toxicity' refers to chemical or physical agents, like radiation, heat, cold, microwaves that under certain circumstances of exposure can cause harmful effects to living organisms (Agency for Toxic Substances and Disease Registry, ATSDR: http://www.atsdr.cdc.gov/). 
impacts' that impair ecosystem dynamics and health, negatively impacting or displacing First Nations. These are in contrast to 'micro-impacts' that refer to the disproportionate placement of polluting industries in poor or ethnic areas, usually urban, whose effects are generally localized. In this thesis, I take up analyses of toxic racism that have usually focussed on urban ethnic minorities and use them as a template for analyzing macroimpacts faced by Aboriginal peoples in Canada.

The toxic racism component of the expanded notion of environmental racism means that we must be cognizant of the environmental burdens experienced by Indigenous peoples as the primary renewable resource users, which occur both at the micro and macro-level, in the context of an exploitive market economy. Indigenous and racial minority communities share similar local 'community' equity issues or microimpacts related to poverty and socio-economics (i.e. environmental health as the result of industrialization, housing, potable water, sanitation, housing, urban air quality, education, employment, etc.). Equity issues arise as a direct result of society's failure to address the political economic context of development (Salazar, 1996) in relation to the cultural and racial conditions within communities which, in themselves, constrain economic options and equitable wealth distribution (Blais, 1996). This is significant since racial minorities rarely if ever experience macro-level environmental impacts (Bryant, 1995; Shanklin, 1997; Swartz, 1994). Negative social, cultural, economic and environmental impacts that contribute to environmental racism are more extensive and heightened for traditional resource users since they are tied to deeply embedded cultural practices. 


\section{Environmental Racism, Governance and Sovereignty}

While there is a large contemporary debate about 'governance' and 'government' both within and without the academy, the model of governance used in the thesis is a fairly conventional. But for all of that, it remains of analytical use (Taylor, 2002). Primarily, I take 'governance' to mean ways that state actors shape their means of governing, be they direct or indirect interventions in states of affairs. It should be noted at the start that the bulk of my discussions of 'governance' refer to the practices of the agents of Canadian state institutions and not to roughly 'equivalent' Aboriginal conceptions of governance. First Nations philosophical approach to governance is one based on respect for the land and the need for responsible action which differs from most state conceptions of governance that emphasis domination and control.

One important example of the use of this state governance concept of domination and control is the use of the 'stakeholder model' as defined by Canadian state processes. In the arena of 'stakeholder analysis' I have self-consciously restricted the scope of my analysis to the discourses of the Canadian state for methodological reasons. In state discourse and practice, 'stakeholder' refers to a party invited to participate in hearings, investigations or environmental reviews but in which these invited 'stakeholder parties' have no legal standing. As such, one is confronted with two practices of state governance. The first is the practice of according legal standing to some and the second is the practice of according 'stakeholder' status to others while being fully aware of the inequality of these two positions relative to state processes and practices. By examining the state stakeholder model, I aim to highlight the racist-exclusionary practices of the 
Canadian state.

The state notion of 'stakeholder' explicitly restricts the capacities of participants deemed so, like First Nations, by not extending legal standing to them. This disables a potential capacity to act as a legal agent amongst others recognised by the state as legal agents, i.e., as bearers and exercisers of legal rights. 'Stakeholder' status, according to the statist model, thus denies First Nations specific legal channels for challenging or redressing legislation, process and the severe, adverse effects of biophysical and sociological degradation and destruction faced by them because of environmental racism. Critically analysing the use of the state stakeholder model is thus distinct from broader analytical stakeholder models that refer to and describe a process in which 'all come to the table as equals'. As my critical analysis of the state stakeholder model shows, this is patently not the structure of Canadian state practices.

Paying close critical attention to the Canadian state's stakeholder model thus allows one to highlight the discrepancies between the representation of an 'equitable' process and the systemic inequalities that allow such processes to exist and that perpetuate them. The false legitimation that occurs thus takes the following form: since First Nations have been included and consulted, the process is 'legitimate'. But, this representation overlooks the unequal status obtained between those with legal standing and those who are mere 'stakeholders'. So, while the process is represented in terms that provide a veneer of 'equality', the difference between these two positions is a structurally unequal: those with legal standing have legal channels open to them and stakeholders do not. 
What is problematic here then, is the veneer of equality on an unequal structure that constrains the capacities of First Nations to act within legal institutions while enabling others. The state stakeholder practice of governance thus is itself a site of racialized inequality, perpetuating under false pretence the injustices visited upon First Nations by environmental racism. In simpler terms, while First Nations, deemed 'stakeholders' are subjected to the risks, harms and damage not of their own doing, those responsible for them and who do not have to live with adverse effects are given greater power because of their legal standing, accorded to them by state practices. Methodologically restricting the notion of stakeholder to the discourses and practices of the Canadian state thus supports my theoretical claim about racist structures in legislation and process. Thus, what I am rejecting is precisely this narrow, state imposed conception of 'stakeholder' on the grounds of its veneer of 'equality, inclusiveness and fairness' and the systemic inequality it both produces and perpetuates.

This model of governance, and the state 'stakeholder model' as an example of, it thus allows one to partially understand the place of Aboriginal persons within the Canadian state. From the point of view of the Canadian state, the governance of Aboriginals (the definition of which is itself a social construct of state institutions ${ }^{3}$ )

\footnotetext{
3. Defining 'Aboriginalness' is symptomatic of this legacy. 'Aboriginalness' or legal identity (Metis, Inuit and Status, and Non-Status Indians) is defined by Federal (and Provincial) statutes, which often determine the degree or extent of Aboriginal entitlement, including ownership and access to lands and resources, and legal recognition. For example, the Department of Indian Affairs and Northern Development and Indian Acts define, in law, who qualifies as a 'Status' Indian, Metis or Inuit. Individuals who do not fit within these state-defined categories, are excluded and no longer considered by the federal government and associated institutions to be beneficiaries or wards of the Crown, i.e., are no longer subjects of the 'doctrine of trust'. Rarely are these definitions and their formulations contested, because of the legal burden this places on the litigant. Approximately half of all Indigenous peoples who have self-identified as to their 'Aboriginalness' are currently not guaranteed equal rights under Federal regulations.
} 
almost exclusively involves treating them as subjects of the Indian Act. Hence, they are seen as being no different than any other Canadian citizen or potential bearer of legal rights as constituted within Canadian state institutions, legislation and process. This positioning of Aboriginals in relation to the Canadian state, is in stark contrast to, and exists in tension with, viewing Aboriginals as sovereign peoples with whom Canada has treaties. If Aboriginals are positioned as sovereign peoples, then they cannot by definition simply be subjects of the Canadian state. Indeed, even the Federal Government and Canadian courts are aware of this circumstance and at times affirm First Nations' sovereignty (cf. RCAP, 1997). However, the pervasive practices and processes of Canadian state governance, contradict this recognition.

While this notion of governance is appropriate to, and helps elucidate the systems, institutions and practices of the Canadian state in its complexities, it is not wholly appropriate to, nor analytically useful for, understanding the organisation and politics of First Nations communities in their diversity and complexity. Consideration of the models and practices of what might be called the 'governance' of First Nations while important, is beyond the scope of this thesis since there are "a panoply of indigenous approaches to governance" (RCAP, 1997: Vol. 2 Chapter 3 'Governance') However, it would not be inappropriate to describe First Nations resistance to, and challenges within Canadian state procedures, as a tactical use of 'juridical models of governance'. In this light, First Nations use the limited capacities of participating in environmental reviews and the courts as means for challenging their fairness, for seeking redress and for drawing attention to their plight. 
At the same time, there are indications that First Nations are productively modifying and appropriating notions of governance as part of their struggle for selfdetermination and sovereignty (RCAP, 1997). Thus, 'governance' has been appropriated in the aim of developing a diversified conception of their own forms of political organisation. Aboriginal visions of self-government embrace two distinct but related goals. The first involves greater authority over a traditional territory and its inhabitants, whether this territory be exclusive to a particular Aboriginal people or shared with others. The second involves greater control over matters that affect the particular Aboriginal nation in question, its culture, identity and well-being. Generally speaking, these goals are made to serve collective interest rather than those related to individual rights and responsibilities. Moreover, in speaking of their traditions of governance, many Aboriginal people emphasize that their leaders were originally chosen and supported by the entire community. 'Governance', for Aboriginal people has thus come to refer to processes for the involvement of all community members in reaching agreement on matters of common interest. Their notion of governance thus stresses that they want greater control over their lives, want freedom from external interference, want to choose and design their own governmental institutions and want to realize their own visions of government as a means for determining their own future.

It is here that we can bring 'sovereignty' into play. In my conception of governance, governance and sovereignty are distinct but related: governance actualises sovereignty. Sovereign rights, which many Indigenous people extol as inherent rights, are partially predicated on the existence of Aboriginal rights concerning lands and resources 
as First Nations. For Indigenous peoples, a definition of environmental racism that is consonant with 'sovereignty' is implicit since control over natural resources is central to resource politics and Aboriginal laws and societies are tied to the land.

The construct of sovereignty belongs, in the main, to statist discourse that has served to set the legal boundaries for international relations. It is used in attempts to justify the control, use and enjoyment of land within territories falling under the sovereign domination of a particular state. States have frequently rationalized their existence through discursive formulations that often treat 'sovereignty' as a sacrosanct principle of legitimation. Racism has become intrinsic to the manner in which Indigenous peoples are framed since nation-states frequently view First Nations as racial 'others' (Smith, 1993). When negotiations pertaining to state authority and land use occur between Indigenous peoples and states, it is frequently the state that sets or controls the agenda, thus attempting to dominate Indigenous peoples by arrogating sovereignty to itself. Environmental racism discourse offers a means to subject state discourse and practice to both internal scrutiny (e.g. to public perceptions of fairness), and external scrutiny (e.g. international human rights).

However, the concept of 'sovereignty', since referring to both empirical and transcendental factors (Bartelson, 1995), is open to contestation particularly in the political realm (Tully, 1995). 'Sovereignty', as a concept and a 'problem', reflects the evolving relationship between state and civil society, political authority and the community (Camilleri and Falk, 1992). To provide congruence in framing my object of inquiry, I do not define 'sovereignty' for Indigenous peoples as 'statehood'. Rather, I 
define Indigenous 'sovereignty' as including both the right of governance (including derivative rights to development: economic, social, cultural and environmental) and what McClure (1995) defines as positive liberty rights, i.e. autonomy/political rights: legislative powers and a relationship of equality, etc). How Indigenous peoples conceive of sovereignty, for example, may imply different conceptions of nationhood. These may include differences over the aspect of consent, social contract and authority and may not conform to currently held state notions or commonly held rhetoric. Simply put, the question of Aboriginal sovereignty is one of who has, or ought to have, the right to make decisions, and according to what procedures. Any adequate analysis of environmental racism must bear this in mind.

It is important to note in this context that First Nations also have legal claims beyond those typical of other minority communities (Kymlicka, 1996), since recognized as 'sovereign' in treaty arrangements (see Chapter Five). Aboriginal environmental racism issues, therefore, involve equity political rights. Equity political rights include the rights to the creation of democratic, culturally relevant, Aboriginal institutions to manage internal affairs without substantive outside interference from the state. This supports the expression of self-determination including the extent of aboriginal legal order. This also heightens the social obligations of the nation state to Indigenous peoples beyond the scope of minority rights. The comparative question is not one of cultural differences but one of state politics and the uneven distribution of political and economic power, and resources between 'founding' nations. Many Indigenous peoples wish to use selfgovernment rights to promote inclusion in the larger economy in ways that will benefit 
them and remain compatible with their cultural values.

\section{De- and Reterritorialization: Sovereignty as a Challenge to the Western Property Rights Regime}

One of many paradoxes one faces in constructing an environmental justice/racism paradigm, is that territorial integrity and sovereignty are conjoined. Present-day

Aboriginal 'sovereignty' issues are about the extent of Aboriginal legal order including actionable rights, and control over lands and resources. As such, environmental racism discourse must, as a requisite, address 'sovereignty' as well as territorial rights due to the exclusionary political arrangements of the Canadian state. These exclusions often involve contemporary constitutional arrangements and resource politics. Indigenous peoples have the right to be active agents, protecting Aboriginal rights. The concept of 'reterritorialization' developed by Connolly (1995), is helpful in this regard. It refers to the process by which the state acknowledges Aboriginal rights to self-determination and authority, including the right of self-governance. Deterritorialization requires states to acknowledge Aboriginal rights to self-determination and authority, and relinquishing a degree of 'sovereign' control. De- and reterritorialization thus refers to the means through which the struggle for 'sovereignty' itself becomes a means for challenging the dominance of the Western property rights regime now imposed on First Nations. Accordingly, Chapter Five will confront the notion of sovereignty with respect to Indigenous peoples, to provide a distinctive, critical and analytical assessment of its relevance to environmental racism discourse. 
Reterritorialization in concert with self-determination, provides the means or vehicle, for Indigenous societies to become truly self-sustaining. Expansion of physical boundaries in 'right-of-title' would provide First Nations with a degree of legal standing, instrumental powers and recourse, while reshaping state geographies. Title is particularly important to Indigenous communities in that it demands constructive dialogue and consent and affords a measure of control over access and use of natural resources, environmental quality, and cultural, economic, and social integrity. A property rights regime that promotes structural, economic, environmental and social justice for Indigenous peoples must also promote human rights and democratic practice through actionable rights. Aboriginal title is not simply a question of past treaty rights but one of social and ecological justice (Orton, 1996). Environmental racism discourse challenges the state's notion of what constitutes racism and demands the deterritorialization of states and state institutions and the reterritorialization of First Nations.

\section{Consequences of Environmental Racism: Neocolonialism, Uneven Geographies of Poverty and Sustainable Development}

Neocolonialism is one of the most pernicious consequences of the conditions constitutive of environmental racism in Canada. Neocolonialism refers to the policies, attitudes, institutions and practices that produce the same effects of 'colonialism', namely the destruction and/or displacement of Indigenous peoples, by means other than direct use of coercive force. Herein, I have defined neocolonialism as displacement of First Nations from their lands and resources by environmental means, namely significant 
environmental impacts or burdens that result in both physical and cultural harm. These negative impacts are usually the direct result of an exploitive market economy in support of private sector-interests and/or the Crown. In the context of environmental racism 'neocolonialism' includes: the modern day erosion of Indigenous 'sovereign' authority and environmental rights, by state governments and corporations. Property rights provide for the ownership of, and controlling interest in, critical resources while sovereignty provides the mechanism for self-determination and governance. Furthermore, both colonialism and neocolonialism produce 'uneven geographies of poverty'. 'Uneven geographies of poverty' refers to those colonialist or apartheid land acquisition policies undermining the economic capacity of First Nation communities to reproduce themselves (Peters, 2001). Both neocolonialism and uneven geographies of poverty undermine 'sustainable development', that is the balancing of economic development, social equity and environmental quality without compromising future generations (cf. Burrows, 1997). A critical use of the expanded concept of environmental racism provides a tool for understanding and challenging neocolonialism and the uneven geographies of poverty that are partially a consequence of it.

\section{Possibilities for Change: From Subordination to Antagonism}

While the situation of environmental racism faced by First Nations in Canada is difficult, change is possible. Here, I think Laclau and Mouffe (1985) have something to contribute since they highlight how political situations can be transformed. According to them, "subordination" refers to a relation in which an agent is subject to the decisions of 
another whereas "oppression" refers to those relations of subordination that have transformed themselves into sites of antagonism. This involves challenging "domination", those relations considered illegitimate from the perspective or in the judgment of, a social agent external to them. The development of the concept of environmental racism as the basis for a critical analytic of the situation faced by First Nations in Canada aims to ally itself with the struggles over the environment facing them. So, while the concept can help examine and expose the on-going oppression and need still experienced in Aboriginal societies, it also has a positive component. I thus aim to indicate how human rights discourse and the discourse of sovereignty may provide useful political tools through which First Nations could deterritorialize their lands and reterritorialize them on their own terms.

However, it is important to note that the conditions and situations of any particular struggle are complex--one must be careful not to view 'Aboriginals' as some unified, 'pure' group with an 'environmentalist' culture. Rather, the expanded analytic of environmental racism attends to the socially constructed capacities of actors and the interests of actors within specific cases. It also appreciates the broader structural inequalities in which actors and interests occur. Thus, as shown in detail in my analysis of toxic racism in Chapter Four, for example, the relationships between Aboriginal communities, the environment, the Canadian state and industrialization are complex. This also means appreciating that there are conflicts within Aboriginal communities surrounding the risks and benefits of challenging industrial development and conflicts over how 'development' should proceed. For some, industrial development is seen as 
positive since providing employment income, and hence economic sustainability. For others, industrial development exactly threatens sustainable communities since leading to the degradation and destruction of biophysical and sociological systems. Thus, there is no "pure" Aboriginal position outside of the social contexts in which 'Aboriginals' are variously socially constructed as particular kinds of actors.

\section{Methodology and Analysis}

I have three objectives in this thesis:

1. To address some of the relevant theoretical assumptions, concepts and principles of environmental racism that apply to First Nations;

2. To provide as evidence a preliminary assessment of some environmental burdens borne disproportionately by Canadian Indigenous peoples, and;

3. Where appropriate, suggest the directions and information needs of future research.

These objective are met by combining my extended concept of environmental racism with data gathered from a variety of sources, itemized below, that are then analysed using the theoretical resources of the expanded environmental racism discourse.

First, I have examined environmental assessment case studies and legal proceedings in order to provide the foundation on which to construct my hypothesis. This review is by no means exhaustive; I simply provide a representative sample. More specifically, I target existing environmental review processes and legislation, welldocumented environmental assessments, agreements and precedent-setting court 
challenges. These provide supporting materials, both quantitative and qualitative, on the existence of environmental racism in Canada. Results are summarized in a general analytic manner. Figure 1 depicts the geographic extent (after Taliman, 1992) of this analysis. Secondly, information is gleaned from academic, peer-reviewed, and 'gray'4 literatures--government, sociological and scientific. Drawing on a wide range of published and unpublished literature helps develop means of conceptualizing First Nations environmental justice issues.

This study takes full advantage of the data and research materials provided by the Royal Commission on Aboriginal peoples (RCAP) which, to date, offers one of the most thorough reviews of Twentieth Century Canadian Aboriginal issues (RCAP, 1997). I have also relied extensively on data contained on three compact disks ('cds'): $c d 1$ Environmental Assessment Panel Reports (123 files, 488 MB); cd2 - Canadian Environmental Assessment Agency Publications (33 files, $243 \mathrm{MB}$ ); and cd3 - Federal Environmental Assessment Review Office Publications (204 files, 217 MB). I have utilized a compendium of Federal environmental assessment initiatives from 1975 to 1997, compiled by the Canadian Environmental Assessment Agency under the heading "Environmental Assessment: The Canadian Experience". ${ }^{5}$ My extended concept of environmental racism and the data gathered from the materials mentioned above, together provide the basis for my critical analysis.

\footnotetext{
4. 'Gray' literatures refers to those sources that have not been peer reviewed or edited.

5 . Copies are available from the Department of Public Works and Government Services (Canada), EN104-9/1997-MRC. Recent environmental assessment reports were acquired directly from the Canadian Environmental Assessment Agency in report format.
} 


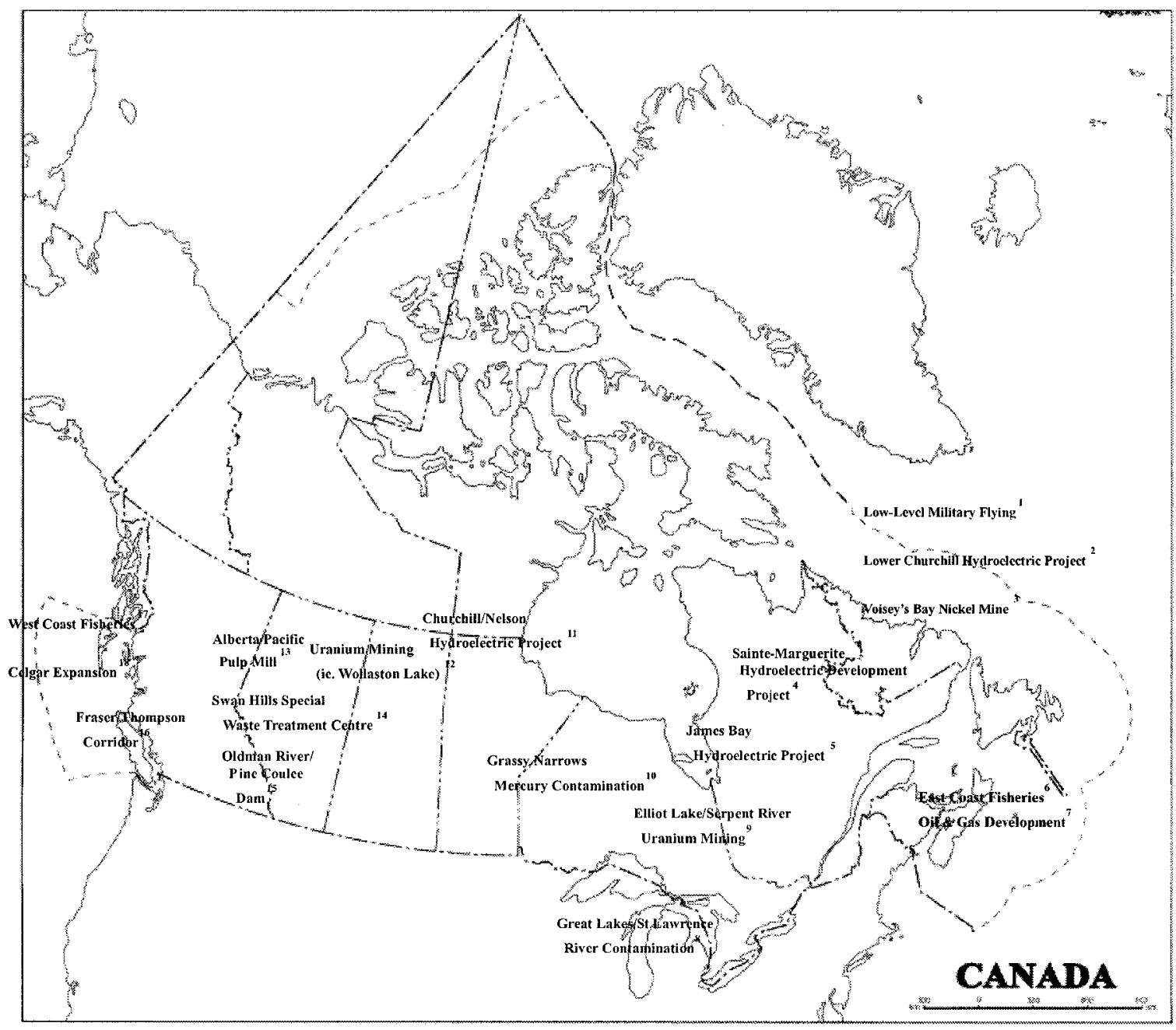

Figure 1:

This figure depicts development activities that can be construed as exhibiting elements of environmental racism. Quantitative and qualitative data given in the text and accompanying footnotes provide proofs of my assertions of environmental racism towards Indigenous Peoples. 


\section{Chapter 3: Patterns of Systemic Racism in}

\section{Legislation and Process}

\section{Introduction}

In this chapter, I attend to patterns of systemic racism in legislation and process. Systemic racism refers to the procedures and policies, including legislation, that exclude First Nations. This then leaves them to manage adverse effects, while often excluding them from economic or social benefits, that are often privatized. The exclusion of First Nations from legislation and process results in a systemic violence of an environmental and sociological nature. This is because human economies and cultures are not separate entities from the environments in which they emerge; rather they are components of an interconnected and interdependent web of life and equally deserving of protection (Fry, 1998). The systemic exclusion of Indigenous peoples means that they are subjected to environmental destruction and degradation, falsely legitimated by the state's exclusionary processes that undermine the environmental and cultural sustainability of Indigenous conditions of existence.

Two instances highlight the environmentally racist character of legislation and process: The Canadian Environmental Assessment Act (CEAA) and the East and West Coast Fisheries. Understanding this data is essential for exposing the environmentally exploitive and exclusionary practices, of state institutions and policies, leading to discriminatory outcomes. Environmental racism, the outcome of this process is a 
consequence of state domination, because of the imbrication of the socio-cultural milieu in the natural environment.

\section{The Canadian Environmental Assessment Act (CEAA): A Critical Examination}

A key component of Canadian environmental legislation, is the Canadian Environmental Assessment $\mathrm{Act}^{6}$ (CEAA). Environmental assessment (EA), as a planning tool, has been practiced by the government of Canada since 1973. A more formal Environmental Assessment Review Process (EARP) was established in 1984 with subsequent recognition by Canadian courts as a law of general application. This law of general application was later replaced by federal legislation, Bill C-13 (Canadian Environmental Assessment Act, An Act to Establish a Federal Environmental Assessment Process, 40-41 Elizabeth II, 1991-92) and conjoining regulations (CEAA, 1993, Comprehensive Study List Regulations, Canada Gazette, Part 1, pp 2845-2906).

Subsequent amendments were made to the Act in March 2001 to strengthen the process. Bill C-9, an act to amend the Canadian Environmental Assessment Act, received royal assent on June 11, 2003 and came into force on October 30, 2003. The Canadian Environmental Assessment Agency (http://www.ceaa.gc.ca/index e.htm) is an independent federal body, accountable to Parliament through the Minister of Environment. The Agency's role is to provide Canadians with high quality environmental assessments that contribute to informed decision-making, in support of sustainable

\footnotetext{
6. Canadian Environmental Assessment Act, An Act to Establish a Federal Environmental Assessment Process, 40-41 Elizabeth II, 1991-92. Amended in 2003 and in force 30 October, 2003.
} 
development. CEAA requires that federal departments, boards and agencies ensure that an environmental assessment occurs before they make final decision about proposed projects. Environmental assessment is used during the planning stage of a proposal to identify and reduce potential adverse environmental effects.

Critics of CEAA contend that the scope of the legislation is too narrow for the following seven reasons (Delicaet, 1995; Sadar and Stolte, 1996). First, the Act limits application to the private sector while ignoring causalities within the public sector (e.g. programs and policies of federal, provincial and territorial governments). Second, it lacks adequate enforcement provisions. Third, it lacks mechanisms for restraining the Minister of Environment. Fourth, the Act provides too close a connection between regulators and regulated (e.g. between Atomic Energy of Canada and Nuclear Industry). Fifth, it builds in too much government discretion. The " 1999 Cabinet Directive on the Environmental Assessment of Policy, Plan and Program Proposals' is a good example of this. It contains strategic environmental assessment and risk analyses and CEAA's 'Operational Policy Statements' on scoping the boundaries of environmental assessment and cumulative effects. Sixth, the Act ignores or dismisses competing resource activities and alternative economic options. Last, it lacks statutory provisions and procedural guarantees for meaningful participation.

Examples given in text, attributed to the Environmental Assessment Review Process (EARP) and subsequent CEAA, share a number of common elements. Most environmental assessments (EAs) are subject to approval by the Governor in Council, and the Prime Minister, although a few have been court-ordered such as the Oldman River 
decision (Friends of the Oldman River v. Canada (Minister of Transport), [1992] 1

S.C.R. 3 101). The Federal Minister of Environment determines the terms and conditions of reviews. The Minister circumscribes the environmental framework of an assessment and advises other ministers on the adequacy of their actions and environmental responsibilities, responsibilities that are not mandatory. Most EAs, prior to CEAA, were politically motivated and hence were the result of public political pressures.

In general, the Canadian Environmental Assessment Act, although a regulated process, is largely an information gathering one, is advisory rather than prescriptive. Its aim is to predict the potential environmental effects of projects requiring federal government participation or approval, whether as a proponent, land manager, source of funding or regulator. For example, the Federal Department of Indian Affairs and Northern Development (DIAND) could be deemed a federal authority i.e., an agency of the Government of Canada or other body established by, or pursuant to, an Act of Parliament, if it so chooses. This stems from the federal government's role in administering the Indian Act and Indian Affairs and Northern Development Act. DIAND is ultimately accountable through a Minister of the Crown, in right of Canada, to Parliament for the conduct of its affairs under the CEAA. This stems from its Federal fiduciary obligations to Aboriginal peoples. There are no provisions for the delegation of decision-making authority beyond the responsible authorities as defined by the act. The actual decision-making authority rests with the Crown.

EAs cannot be used to invade or unduly intrude in matters of provincial jurisdiction. Hence, EAs are primarily bilateral agreements between federal and 
provincial or territorial authorities, which frequently ignore Aboriginal rights and claims. Often, the federal government exercises caution with respect to provincial authority while discounting Aboriginal authority, by determining the range and scope of factors that may be taken into account in the EA process. Although the process is mandatory and professes to promote sustainable development, its conclusions are non-binding and frequently partisan. Further, the federal guide to cumulative effects assessment places the emphasis almost solely on biophysical effects, neglecting sociological ones.

One of the key concepts of this legislation is 'sustainable development' which this act professes to promote. 'Sustainable development' refers to development that meets the needs of the present without compromising the ability of future generations to meet their own needs. This legislation proposes to achieve sustainable development by conserving and enhancing environmental quality and by encouraging and promoting economic development that conserves and enhances environmental quality, while providing an effective means of integrating environmental factors into planning and decision-making processes (http://laws.justice.gc.ca/en/C-15.2/text.html).

It is my intention to expose the irony behind this statement by revealing the discriminatory nature of this legislation with respect to First Nations. I have used this legislation and subsequent reviews to provide supporting evidence for my claims of neocolonialism and, subsequently, environmental racism. As noted above, neocolonialism refers to institutional arrangements, practices and ideologies that produce the effects of domination and displacement characteristic of 'colonialism' but by 'indirect means' like environmental degradation. These effects discriminate against, and 
significantly disadvantage, First Nations.

My analysis of CEAA shows this piece of legislation does not acknowledge Aboriginal rights in land or in authority, in any substantive manner. Rather, the amended legislation, where it does reflect on Indigenous authority, only makes specific reference to reserve lands or lands selected in claims settlement agreements. ${ }^{7}$ CEAA lacks statutory provisions or procedural guarantees to protect Aboriginal rights in land. This is particularly true for unsecured and/or extraterritorial lands and resources.

For example, military low-level training flights (500-1000 feet) are currently being conducted out of Canadian Forces Base (CFB) Goose Bay, Labrador, over designated areas of Labrador and Quebec that total $100,000 \mathrm{~km}^{2}{ }^{8}$ After fourteen years of low-level military flying, there remains considerable scientific uncertainty on the effects of low-level flying on human health, wildlife and the environment. In the past, the Department of National Defense did not seek First Nations approval, though the area is subject to several outstanding land claims. The panel did note, however, that settlement of outstanding land claims would encourage an open dialogue with Aboriginal communities.

\footnotetext{
7. See Figure 1. Most of the substantive settlement agreements are north of $60^{\circ}$ in the northern territories: Yukon, Northwest Territories and Nunavut, which have been subject of modern land claims agreements. Typically, these agreements include full rights of beneficial ownership of certain lands in the area covered by the agreement. These often enable the coexistence of otherwise competing systems of land tenure, governance and sovereignty, and provide a degree of formal recognition of extraterritorial rights including wildlife harvesting rights, participation in land, water, wildlife, heritage resources and parks, and environmental management, financial compensation, resource revenue sharing and development rights. These agreements provide stipulations for delegation of authority, in this instance, environmental impact assessments, and regulatory authority to Indigenous bodies through Constitutional provisions. Areas north of $60^{\circ}$ in Northern Quebec and Labrador are atypical as they are confined within provincial boundaries and face the same prejudices as their provincial counterparts.

8. Canadian Environmental Assessment Agency (CEAA), Military Flying Activities in Labrador and Quebec, Supply and Services Canada, Ottawa, Canada, 92 p., February, 1995.
} 
However, there are no statutory provisions or procedural guarantees that this will occur.

Similarly, fragmentation of bottom lands in the Fraser-Thompson Corridor ${ }^{9}$ by rail lines, highways, transmission lines and pipelines are seen by Indigenous peoples as both an intrusion on land claims as well as further impairment of critical bottomland ecosystems and cultural components. As it stands, existing environmental legislation discounts those Indigenous peoples who have yet to secure some semblance of legal recognition, including rights in land, through constitutional or legislation provisions.

Arguably, environmental legislation such as CEAA should not be used to invade or unduly intrude in matters of Aboriginal jurisdiction. Intrusions on Aboriginal authority, suggests that the current environmental assessment process is flawed since, in effect, it supports intrusive resource development activities rather than providing means to challenge or oppose them. These often lead to intrusive discriminatory environmental outcomes. (Examples of such outcomes in the East and West coast fisheries are discussed later in this chapter).

\section{CEAA Legislation and Process as a Contravention of Human Rights}

The environmental racism inherent in CEAA may be construed as a breach of environmental human rights in that it supports racist practice. As a result of the internalization of human rights (e.g. International Covenant on Economic, Social and Cultural Rights, Article 25 and Universal Declaration on Rights of Indigenous people )

\footnotetext{
${ }^{9}$. Federal Environmental Assessment Review Office (FEARO), Fraser-Thompson Corridor Review, Supply and Services Canada, Ottawa, Canada, 52 p., January, 1986.
} 
and the environment (Brundtland Report: World Commission on Environment and Development, 1987 and Rio Declaration: United Nations Conference on Environment and Development, 1992), international bodies have increasingly recognized that another legitimate human right exists which combines issues of self-determination along with the accompanying derivative rights of social justice concerning the environment. Jointly, these rights have been referred to as 'environmental human rights' (Popovic, 1996). Some of the basic tenets of environmental human rights include: the inherent right of all peoples, including Indigenous peoples, irrespective of state, to enjoy and utilize fully and freely their national wealth and resources, and the concurrent right to a clean and safe environment. Development of these rights are in their formative stages but are increasingly acquiring broader legal and moral foundations. Environmental human rights discourse, not unlike the environmental racism analytic, offers Indigenous peoples another venue in which to press claims of state injustice. ${ }^{10}$

Within existing environmental legislation such as CEAA, Indigenous peoples are frequently consulted as 'stakeholders' instead of as the bearer of substantive legal rights beyond those of the average citizen. Current legislation does not recognize Aboriginal authority and claims. For example, even recent government policies such as the Canadian Cabinet Directive on the Environmental Assessment of Policy, Plan and Program Proposals (1999), avoid mention of any legal obligation to Indigenous peoples. Policy directives are the vehicle of legislative implementation and this absence clearly suggests 
they believe these obligations can be ignored.

Within existing legislation, it is difficult to limit the powers of the Minister of the Department of the Environment if s/he fails to protect the environment or Indigenous property rights. Instead, the fiduciary obligation to protect Aboriginal interests rests with other Federal institutions such as the Department of Indian and Northern Affairs, Federal Interlocutor Secretariate for Metis and Non-Status Indians within the Privy Council Office, and to a lesser extent, Justice. These agencies are limited by legislative, legal and institutional constraints even when they choose to act.

Because of Ministerial discretion, the state sets or controls the environmental agenda. Environmental Impact Assessment (EIA) review panels are frequently advised not to assess the scope or substance of Indigenous claims (Fry, 1998). In seventy-eight percent of cases noted above (i.e., fourteen of eighteen case studies--see Figure 1), review panels were explicitly advised to ignore Indigenous claims of land use and occupancy. This disregard for Indigenous property rights, usually on contested 'Crown' land, can be construed as a violation of their human and environmental rights if one applies the criteria of the International Covenant on Economic, Social and Cultural Rights. Governments frequently violate Aboriginal rights-in-land, including those of title, due process (procedural fairness and equity) and consent when promoting resource development activities. This contravenes the International Covenant on Economic, Social and Cultural Rights, to which Canada is a party, which provides for 'security of property' as a fundamental human right. According to this covenant, the state cannot arbitrarily take ownership or control of held land, and resources belonging to, Indigenous peoples. 
These regulatory failures disproportionately affect Indigenous lands, both secured and unsecured, and resources with little or no compensation, recourse or remedy. Consequently, this confines Indigenous communities to unsustainable holdings and blatantly disregards the viability of Indigenous biophysical and sociological systems. State procedures of this kind are racist since they isolate, separate and exploit Indigenous peoples with predictable distributional impacts, disproportionately borne by them. This is in keeping with what comprises environmental racism. All too often, Indigenous communities are left to bear the brunt of significant environmental, cultural and social burdens. These impacts affect traditionalists especially, since they rely on natural ecosystems for most of their biophysical and cultural needs. This implies that the Minister of Environment, in right of the Crown, condones, is oblivious to, or is ambivalent, with respect to his/her social, legal and moral obligations toward First Nations. Yet, the state seems to recognize that in order to conserve biodiversity including endangered species, one must protect habitat or space but does not apply this premise to cultural diversity (Species at Risk Act, SARA, Bill C-29, 2002).

The exclusion of First Nations from legislation and process, as noted above, results in systemic violence/racism of an environmental and sociological nature leading to discriminatory outcomes and exploitation. CEAA legislation and process has all the trappings of environmental racism since the predictable impacts of these decisions and processes contributes to the institutionalization of racial subordination and domination towards Indigenous peoples through environmental degradation. This contravenes the expressed purpose of this legislation 'to provide Canadians with high quality 
environmental assessments that contribute to informed decision-making, in support of sustainable development'. This legislation does not protect Aboriginal environmental human rights. Moreover, it lacks statutory and procedural guarantees, i.e., due process and consent. Canadian environmental legislation, if it is to be consistent, must be prescriptive and accountable to First Nations under international human rights provisions. The concept of sustainable development, of both the environment and culture, in environmental legislation and process must be made mandatory, to challenge and oppose state environmental racism.

\section{Flawed Legislative Process and Systemic Racism in the Fisheries}

Perhaps less evident than the CEAA process but equally disturbing, are the exclusionary institutional arrangements governing the East and West Coast Fisheries, contributing to environmental racism. The environmentally racist character of legislative process concerning the East and West coast fisheries can be traced back to the failure of the Canadian state to respect both the constitutional and human rights of First Nations to extraterritorial rights, including rights to wildlife harvesting and participation in land, water and wildlife heritage resources.

During the second half of the nineteenth century, Native Peoples in Nova Scotia, New Brunswick and Quebec were systematically excluded from the Atlantic fishery. Parenteau (1998) contends that the agency primarily responsible for Aboriginal exclusion from the fisheries was the Federal Department of Fisheries and Oceans and argues that this has transformed Indigenous peoples in the Maritimes from active resource users to 
cultural commodities.

Environmental racism, per se, is less evident on the East coast, compared to the West coast, as successive generations of Indigenous fishers (e.g. Mikmaw) have been denied their historical rights of access to coastal marine resources. As a result, evidence of environmental racism including cultural, social, economic and environmental impacts have been obscured or diminished over time, masking these chronic effects. However, the Marshall case, a court challenge of East coast fishing regulations, provides compelling evidence of the continuance of marine resource use, despite severe limitations imposed by the state (R. v. Marshall, [1999] 3 S.C.R. 38). These controls have been exacerbated by recent declines in the fish stock because of over-fishing by multinational conglomerates. Up until Marshall, much of the remaining Aboriginal fishery was marginalised or driven underground due to institutional regulatory biases.

With respect to the West Coast Fishery, Regina v. Sparrow, ([1990] 1 S.C.R. 1075) held that while there was federal power to regulate the exercise of fishing by Indians, the power was limited by s. 35 (1) of the Constitutional Act, 1982. According to this section, historical policy on the part of the Crown can neither extinguish the existing Aboriginal right without clear intention nor, in itself, delineate the right. Legislation that affects the exercise of Aboriginal rights will be valid if it meets the test for justifying an interference with a right recognized and affirmed under s. 35 (1). ${ }^{11}$ A generous, liberal interpretation is appropriate given that the provision aims to affirm Aboriginal rights and

\footnotetext{
${ }^{11}$. The section reads: "The existing aboriginal and treaty rights of the aboriginal peoples of Canada are hereby recognized and affirmed".
} 
must be interpreted flexibly to permit their evolution over time. Federal power must also be reconciled with federal fiduciary capacity and the best way to achieve that reconciliation is to demand the justification of any government regulation that infringes upon or denies Aboriginal rights.

Section 35 (1) provides a solid constitutional base for subsequent negotiations. The courts contend that this constitutional provision protects Aboriginal peoples against undue intrusion by provincial legislative power. However, fishing rights are not traditional property rights. Rather, they are rights held by a collective and are in keeping with the culture and existence of the group. Here, regulation amounts to prima facia interference if found to be an adverse restriction on the exercise of a natives' right to fish for food.

Also, there must be a link between the question of justification and the allocation of priorities in the fishery: Aboriginal peoples must be given first consideration, affirming Aboriginal rights. Thus, Indian Food Fishing is to be given priority over the interests of other user groups. For example, Regina v. Gladstone, ([1996] 2 S.C.R. 723) held that the accused's attempt to sell herring spawn on kelp (commercial sale), was an Heiltsuk traditional practice that could not be curtailed in light of the government's inability to provide evidence that the regulatory scheme was justified.

In another decision, Delgamuukw v. British Columbia, ([1997] 3 S.C.R. 1010) held that subject to accommodating Aboriginal peoples' interests, the Crown's infringement of Aboriginal rights could be justified to further certain legislative objectives such as economic development. However, the province had no authority to 
extinguish Aboriginal rights either under the Constitution Act, 1867 or by virtue of s. 88 of the Indian Act. The appellants' Aboriginal rights were not extinguished before 1871 and they had unextinguished non-exclusive Aboriginal rights in certain lands. The test for determining whether a claim could succeed required the groups asserting title to satisfy that they occupied the lands in question at the time when the Crown asserted sovereignty and that it continued to exclusively occupy and use the land as part of its traditional way of life.

\section{Systemic Racism and the Department of Fisheries and Oceans (DFO)}

Evidence of systemic racism is also found when one examines the practices and processes of the federal government's Department of Fisheries and Oceans.

Characteristically, these involve the role of the DFO as an agent of the Crown that disregards Aboriginal rights, restricts policy and legislative agendas and engages in political interference. Consequently, with respect to the East Coast Fisheries and West Coast Fisheries, DFO has been more inclined to recognize public and corporate commercial interests over Aboriginal harvesting rights. This disregard became ingrained in the governments' institutional culture.

Since policy is a function of parliament, it would seem that DFO, as an arm of government, has failed to acknowledge Aboriginal rights dating back to the Royal Proclamation of $1783 .{ }^{12}$ These instances indicate that the Federal government operates in

12. Source: Brigham, British Royal Proclamation, volume 12, pp. 212-218. This is the most accurate printed text of the Proclamation. A less accurate version is reproduced in the Revised Statutes of Canada 1985, Appendix II, No. 1. 
accordance with a colonialist framework. Not unlike the Canadian Environmental Assessment Agency, DFO as a public institution, opted to treat Indigenous peoples as 'stakeholders'. Stakeholders are third-party interests, any person or body, who has an interest in the outcome of resource (fisheries) management initiatives for either environmental, social or economic purposes that are neither frivolous nor vexatious. Stakeholders may offer a considered opinion but do not have institutional authority. Thus, DFO fails to treat Aboriginals as bearers of rights according to the Marshall decision (R. v. Marshall, [1999] 3 S.C.R. 38.).

However, when negotiations have occurred with respect to Aboriginal rights in the offshore, it is often state institutions that set the agenda or frame the object of inquiry, hence relying on exclusionary processes, regardless of Aboriginal claims. On-going negotiations between DFO, representing the state, and First Nations, indicate that the government persists in narrow readings of the rulings mentioned above. Thus, the state sets limits on Aboriginal rights by continuing to define what constitutes a moderate livelihood, community access and boundaries, availability and limits of quotas. This is in sharp contrast to a more liberal, equitable stance as suggested in Regina v. Sparrow, ([1990] 1 S.C.R. 1075), and hence substantive change and justice is protracted. These delays can be construed as form of institutional bigotry and a wrongful use of power since they institutionalize unconscious biases, exclusionary processes and normative judgments influencing racially meaningful social structures (Foster, 1993). For example, it is Canada's policy-stance to seek resolution to the satisfaction of all parties (public, provincial, private and third-party interests) irrespective of Aboriginal rights to, or on, 
these same holdings.

Political interference was also a contributing factor to the fisheries process. Over time, this became the norm. DFO regulation resulted in Aboriginal fishers being excluded from most commercial and, in some instances, domestic fishery, irrespective of Aboriginal harvesting rights (cf. Parenteau, 1998). For example, recently, DFO and the National Energy Board may have acted inappropriately by not considering Aboriginal proprietary interests in the Venture Development Project review since there continues to be no clear understanding of residual inherent rights, including extraterritorial rights, that Indigenous peoples may retain (Berman, 1994). ${ }^{13}$

The Venture Development Project, Sable Island, includes the development of offshore platforms and transportation of the gas and condensate to an onshore gas plant through a sub-sea pipeline, a landfall terminal and an overland pipeline system. A recent Court of Appeal decision ruled that the regulator's (National Energy Board, NEB) approval process was invalid, that is, was a breach of procedural fairness, since the environmental assessment did not address how Mi'kmaq would take part in the use and monitoring of the overland pipeline system. The court challenge did not speak to the loss of marine resources in the event of a spill.

Currently, the Department of Fisheries and Oceans has been given the mandate by the Federal government to negotiate fishing agreements that will provide increased First Nation access to the fishery on an immediate basis. This seems to transfer authority for 
negotiations to an agency not restrained by the Indian Act. DIAND still leads on issues of Aboriginal rights, title and treaty rights (cf. Parenteau, 1998), but does seem to have been given authority with respect to offshore environmental and cultural rights.

\section{The Collapse of the Fishery}

The collapse of crucial components of various fisheries (e.g. cod, salmon and abalone fisheries on the East and West coasts respectively) within Canada's marine ecosystems is somewhat the result of commercial exploitation by international conglomerates. Ironically this seems to be taking place at a time when the courts have finally recognized Aboriginal subsistence and commercial rights (R. v. Marshall, [1999] 3 S.C.R. 38; Regina v. Sparrow, [1990] 1 S.C.R. 1075; Regina v. Nikal, [1996] I S.C.R. 1013; Regina v. Gladstone, [1996] 2 S.C.R. 723; Delgamuukw v. British Columbia, [1997] 3 S.C.R. 1010).

Concerning the collapse of various fisheries, there are solid reasons for treating 'the denial of access to follow traditional pursuits' as environmental racism. This has been compounded by federal authorities allowing commercial interests to threaten the stock, further restricting rights. They have also allowed the pollution of the fisheries that may no longer be fit for consumption (e.g. shellfish). Similarly, marine ecosystem diversity and populations have progressively deteriorated over the course of a century rather than dramatically, as has occurred on the West coast where Aboriginal fishers have a continuous record of subsistence exploitation. Historically, neither the federal nor provincial governments have recognized or clarified, in any substantive manner, the 
extent of Aboriginal rights-in-law to offshore resources. Rather, a licensing system was established that favoured commercial interests and Maritimers of European decent.

The commercial fisheries, however, may not be the sole perpetrators. Rather, other commercial ventures such as seismic work related to non-renewable resources exploration (e.g. oil and gas venues) and oceanographic mapping, shipping and landbased sources such as pulp and paper effluents (see Chapter Four) are responsible for contamination of bottom sediments by persistent organic and inorganic pollutants (e.g. sunken oils), which significantly interfere with ecosystem population dynamics such as species diversity and health, further jeopardizing Aboriginal resource harvesting rights.

\section{Discussion}

The systemic racism within the legislative process produces the concrete effect of environmental liabilities. Liabilities highlight the extent to which development activities negatively influence land claim negotiations. Restrictions placed on First Nations by state qualifications of 'Aboriginalness', constitutional, legislative and statutory provisions, have important implications for access to land, legal standing/rights and access to government programmes and services. The reduction of First Nations to the status of mere 'stakeholders', as defined by state processes, is indicative of the state's active exclusion of First Nations and their rights. The case of the fishery exemplifies the social and cultural polarization faced by First Nations as a result of the destruction of their cultural, social, environmental and community economic fabric.

Assessments of these developments frequently proceed without due regard for 
Indigenous biophysical and sociological systems. Instead, the Federal government bargains with the province(s) on what the province, and subsequently, the Crown, is willing to concede to First Nations. Cameron and White (1995) argue that devolution of power or authority (for example, via Natural Resource Transfer Agreements) from the federal government to the provinces is an improper abrogation of Canada's fiduciary responsibilities with respect to First Nations and could be interpreted as complicity or collusion.

For example, in the Oldman River Dam and Pine Coulee Water Management Projects, the final settlement was imposed by the Alberta government. ${ }^{14}$ The Oldman River Dam panel itself concluded that the Alberta government, as proponent, and the Peigan, failed to come to terms over this project. This is one of the most significant and unacceptable features of the project. In the first instance, the Oldman River Dam, the Federal Court of Appeal referred the project for public review in March, 1990 requiring that federal authorities comply with the Environmental Assessment and Review Process Guidelines Order. The dam itself is located just downstream of the confluence of the Crowsnest, Castle and Oldman Rivers with the reservoir extending twenty-four kilometres in length and holding 490 million cubic metres of water. The project was ninety-five percent completed at the time of the public hearings in June 1991 and completed in the fall. The hearings on environmental and socio-economic issues were

\footnotetext{
14. Federal Environmental Assessment Review Office (FEARO), Oldman River Dam, Supply and Services Canada, Ottawa, Canada, 56 p., 1992 and Canadian Environmental Assessment Agency (CEAA), Pine Coulee Water Management Project, Supply and Services Canada, Ottawa, Canada, 249 p., February, 1995.
} 
held in November after the fact.

In the second instance, the Alberta Public Works, Supply and Services (PWSS) requested approval to construct the Pine Coulee Project that includes a diversion weir, a $3.5 \mathrm{~km}$ canal and a multiuse, off-stream storage reservoir. Water will be diverted to the Pine Coulee Reservoir. The Pine Coulee Project is part of the Oldman River Basin. Not unlike the Oldman River Dam the primary goal of the project is to secure water for municipal use, irrigation (used to accommodate agricultural usage) and recreation. The Peigan Nation again expressed its concern that the proposed project would interfere with its claim to water rights believed to be conferred by Treaty 7 . But, the 'Alberta' panel's response was that it does not owe a fiduciary duty to Aboriginal peoples. Once again, Aboriginal members of the Blackfoot Confederacy are environmentally exposed. This supports the contention that First Nations continue to be cleared from their traditional holdings, albeit in an increasingly more subtle fashion, and continue to be more socially, culturally, environmentally and economically marginalised.

\section{Conclusion}

The concept of environmental racism helps elucidate racial biases, and systemic violence, found in self-serving land-use and environmental legislation and policies, within national and provincial institutions. These reflect the views of the dominant society and, in effect, support the status quo. It is evident from both quantitative data (primarily historical and geographical), and qualitative data concerning the CEAA and the East and West Coast Fisheries, that Canadian First Nations continue to experience 
displacement from their lands and resources be they territorial or extra-territorial. This displacement occurs through state regulation of renewable and non-renewable resource activities. These interfere with traditional pursuits yet rarely provide substantive economic and social benefits to First Nations. Racial and systemic biases are indicative of persistent environmental racism. These can be traced back to imperialist doctrine, in conjunction with exclusionary environmental, political, economic and social forces.

Federal environmental legislation, such as the Fisheries Act and CEAA, does not address or recognize social justice issues, such as fairness and equity, nor does it question the distribution of power and authority. Rather, legislation is crafted in a manner that supports existing state structures and institutions, hence, existing oppression, thus denying and undermining justice. Both acts go to great lengths to ensure that legislation entrenches the provincial, jurisdictional and legal authority of the Canadian state, whereas neither act acknowledges Indigenous authority or rights. Thus, environmental legislation aims at something other than justice. East and West Coast Fisheries cases provide evidence of these systemic injustices.

Being the sole regulator of social distribution, government actions fortify exclusionary processes, thus sedimenting racism and systemic violence concerning the environment. Their effect, while 'indirect' repeats, in new ways, earlier colonialist practices of displacing Aboriginals from their traditional environments, thus undermining their capacity to sustain and/or shape their way of life.

These acts of environmental racism are in direct contravention of international human rights (that speak to security of property and by extension, the right to a safe and 
secure environment) and are not in keeping with the concept of 'sustainable development'. Thus, Canadian government legislation and process contradicts one of the explicit aims of the CEAA. These attacks on Indigenous lands and resources, whether intended or not, continue to endanger First Nations communities. It is also evident from the contextual data discussed above, that there is an ongoing failure by state governments to recognize or acknowledge, how racist tendencies associated with colonialism and present-day neocolonialism, are reflected in, and still infuse, land-use practices. This erodes or denies Aboriginal human rights.

The crux of the matter is this: at core, these exclusions in legislation and process that isolate, separate and exploit First Nations, have predictable distributional impacts. These include environmental, social, cultural and economic disparities creating uneven geographies of poverty. This is because First Nations receive little or no benefit from developments and are subjected to their adverse effects that undermine means of subsistence, be they biophysical, sociological or cultural. This almost immediately leads to both the physical and environmental displacement of Indigenous peoples from their lands and resources. Environmental racism discourse thus exposes exclusionary and racist biases in the state-sanctioned systemic violence directed disproportionately towards First Nations' land and resources.

In the next chapter, I examine toxic effects of environmental racism that are falsely legitimated by flaws in legislation and process. Moreover, these toxic effects also highlight how the exclusion of First Nations in the environmental policy process has cleared a path for provinces and private enterprise to exploit the environment for their 
own benefit. Indigenous peoples are then left to deal with the adverse effects of toxic racism. 


\section{Chapter 4: Four Facets of Toxic Racism:}

\section{Food Contamination, Ecosystem Health, Noise Pollution and}

\section{Electromagnetic Radiation}

\section{Introduction: Toxic Racism and Macro-Impacts}

In this chapter, I attend to the racists effects of toxicity and its macro-impacts on First Nations as a component of the expanded concept of environmental racism. 'Toxic' refers to biophysical and sociological impairment of ecosystem functions where the productivity and quality of the environment is diminished or impaired and human health is compromised. Examining macro-impacts, as noted in Chapter Two, precludes having to address more localized issues or micro-impacts, such as potable water, sanitation and housing. In particular, I am concerned with exploring and examining the macro-impacts of toxic agents on the sustainability of First Nations ways of life. Toxic agents are chemical or physical agents, e.g., radiation and microwaves, that under certain circumstances of exposure can cause harmful effects to living organisms (Agency for Toxic Substances and Disease Registry, ATSDR: http://www.atsdr.cdc.gov/). Macroimpacts usually have extensive effects on large geographical areas, impair ecosystem dynamics and health, and displace and/or negatively impact First Nation sustainability. My analyses of toxic racism focus on four kinds of toxic effects, detailed in a number of CEAA environmental assessment cases:

- The contamination of the food chain; 
- Ecosystem health, habitat loss and overexploitation;

- Noise pollution; and

- Electromagnetic radiation

In the case of food chain contamination, I discuss the toxic effects of uranium mining, mercury poisoning, hazardous waste incineration and pulp and paper production, particularly on 'country foods'. 'Country foods' refer to edible flora and fauna, taken by First Nations, from land or water, be they, as food or as medicines.

Pulp and paper production highlights threats to ecosystem health, habitat loss and overexploitation. Military low-flying in Northern Quebec and Labrador illustrate the toxic effects of noise pollution. Last, I examine the toxic racist effects of electromagnetic radiation in Manitoba and Wisconsin as a consequence of high voltage transmission corridors. These examples reflect the insidious nature of toxic racism and how environmental burdens adversely impact Indigenous land and societies. In fact, Aboriginal peoples are often targets of toxic development because of their vulnerabilities. After analyzing these cases, I then discuss the role of the state and capitalist development on toxic racism, the consequences of toxic contaminants for assessing risks. I conclude with some remarks on toxic racism and human rights.

It is important to note that toxins in the environment have both cumulative impacts and potentially synergistic effects. In the case of cumulative impacts, one is dealing with augmenting, gaining, or giving force by successive additions of toxic agents. In the case of 'synergy', it is not uncommon for the effect of two chemicals on an organism to be greater than the effect of each chemical individually, or the sum of the 
individual effects. That is to say that the presence of one chemical enhances the effect of the second. The complexity of interactions provides justification for the 'precautionary principle' which states that 'where there are threats of serious or irreversible damage, lack of full scientific certainty shall not be used as a reason for postponing cost-effective measures to prevent environmental degradation'. This circumstance also requires that the analyst exercise some caution as well. I have aimed to substantiate the claim of toxic racism by discussing only those examples where a body of evidence has been documented in sufficient detail and where assertions become sufficiently compelling to substantiate the existence of environmental racism. However, this material only represents the "tip of the iceberg' since well-documented evidence is generally scarce. But, given time and resources, I contend that one would find that toxic racism with respect to Indigenous peoples in Canada is quite prevalent--and even increasing--as a result of contemporary neocolonialism.

\section{The Current Governmental Context and 'Externalities'}

Currently environmental protection in Canada largely rests on a combination of technological innovations, market-forces and government regulations. The predominance of economic and policy discourse is technocentric since it excludes the direct use of moral and ethical imperatives such as social accountability, compensation and the precautionary principle (Beck, 1992). All too often, Indigenous communities that have the least political power or social resources to defend themselves against unfettered commercial development are the most vulnerable to these racist practices. Human rights 
violations may in fact be a precursor or a subsequent result of social, environmental and cultural deterioration.

To date, no comprehensive surveys have been conducted on compromised ecosystems associated with Indigenous 'lands' (Goldtooth, 1995). Neither has any legal authority, be it, federal, provincial or corporate bodies, acknowledged responsibility for compromised ecosystem on which First Nations' economies rely. Rather, economists and policy analysts treat many of these environmental impacts as 'externalities' since the marketplace often fails to account for environmental and social costs (Goldman, 1993). 'Externalities', in reality, refer to 'macro-impacts. Thus, I examine externalities associated with an exploitive resource economy such as resource extraction activities or ecosystem degradation found in mining, oil and gas development, forestry, pulp and paper mills, impoundments, runoff, ocean dumping, etc. These elements are the most socially and environmentally disruptive to First Nations. This is especially true for those areas involving uncertain yet potentially catastrophic, irreversible, or inequitable impacts.

There has been a long established legal principle that states have a duty not to allow their territory to be used for acts, such as pollution, that harm other states. This principle was articulated in the 1942 Trail Smelter Arbitration between Canada and the U.S. and was one of the first legal cases to address liability for environmental damages (Trail Smelter Arbitration, United States v. Canada, (1931-41), 3 R. I. A. A. 1905; Tarlock, 1997). These principles of environmental law generally have become entrenched in domestic law in most countries including Canada. This case also served as one of the forerunners, both internationally and domestically, to the 'polluter pays', 
'environmentally sound' and 'sustainable development' principles (http://www.justice.gc.ca/en/dept/pub/sds/susdevstrategy1998/obj3.html). However, these principles and legal liabilities have not been tested interprovincially or between First Nation peoples and provincial and federal governments. I believe that if the courts were allowed to rule on Indigenous cases of toxic racism, it would hold both the federal and provincial governments to a much higher standard of care with regards to First Nations' lands and resources. Further, the courts would likely find both provincial and federal governments liable for punitive damages or restitution as a result of their reckless and perhaps, deliberate, disregard for Aboriginal environmental, cultural and social health. In this light, environmental justice would require a more equitable treatment of Indigenous peoples that does not place them at risk environmentally, culturally, socially and economically. Without holding states accountable, environmental racism will continue to operate at a state level, unabated.

\section{Food Chain Contamination}

Food chain contamination occurs through the introduction of toxic substances into the environment. This results in increased concentrations of toxins, making them more pathogenetic, as they move through the food chain, from plant, to animal to human, for instance. In terms of the expanded analytic of environmental racism, the contamination of country foods produces a form of genocide via the environmentally racist failure of governments to stop polluters, or effectively displaces First Nations by undermining conditions of sustainability. Both of these effects of the toxic contamination of the food 
chain can thus be construed as neocolonialist. In this section, I examine food chain contamination caused by uranium mining, the mercury poisoning of water, pulp and paper production and hazardous waste treatment.

\section{Uranium Mining and Food Chain Contamination}

Instances of toxic racism surrounding uranium mining, and the failure of the state to follow the precautionary principle with regards to the sustainability of First Nations, highlight the environmentally racist effects of food chain contamination. These are forcefully highlighted in the cases of uranium mining in Northern Saskatchewan and Elliot Lake, Ontario.

An environmental assessment panel, of a technical nature, was established in 1991 to review the environmental, health, safety and socioeconomic impacts of the proposed McArthur River Underground Exploration, Dominique-Janine extension, Midwest Joint Venture and McClean Lake, McArthur River, Midwest and Cigar Lake Projects in Northern Saskatchewan. ${ }^{15}$ The review dealt with the mining of nine ore bodies, the construction of one mill, the design of two tailings management facilities and the expansion of the transportation system.

The conclusions and recommendations represented were based on accumulated

15. Federal Environmental Assessment Review Office (FEARO), Rabbit Lake Uranium Mining, Supply and Services Canada, Ottawa, Canada, 47 p., November, 1993; Federal Environmental Assessment Review Office (FEARO), Dominique-Janine Extension, McClean Lake Project, and Midwest Joint Venture, Supply and Services Canada, Ottawa, Canada, 66 p., October, 1993. (Wollaston Lake); Canadian Environmental Assessment Agency (CEAA), McArthur River Uranium Mine Project, Supply and Services Canada, Ottawa, Canada, 75 p., February, 1997; and Canadian Environmental Assessment Agency (CEAA), Midwest Uranium Mine Project, Cigar Lake Uranium Mine Project and Cumulative Observations, Supply and Services Canada, Ottawa, Canada, 161 p., November, 1997. 
knowledge of the entire industry for the period 1991 through 1997 as provided in the reports listed above. The scope of the environment assessment processes was, however, defined in 1991. The panel hearings paid particular attention to concerns of northerners, whom they felt would experience the greatest impacts of uranium mining. This was to ensure residents would be protected from adverse environmental impacts. However, acceptable environmental quality standards and protection and environmental damage was based solely on legislative, scientific and technological guidelines and thus was exclusionary. From a scientific standpoint, the panel concluded that it is unreasonable to expect that it might be possible in the foreseeable future to 'walk-away' from sites containing millions of tonnes of material that are both radioactive and toxic.

There are similar circumstances surrounding the predictable environmental impacts associated with the Rabbit Lake Uranium Mine and those in the immediate vicinity. First, there is the matter of the immediate physical displacement caused by the mine itself. They include: outbuildings, tailings pond, shaft, roads, etc. These displacements result in significant habitat loss. Second there is the matter of toxins released into the air, land and watersheds. Among these toxins are radionucleides and heavy metals. These contaminants often pose an immediate threat to human and environmental health.

For example, at the Rabbit Lake Uranium Mine, effluents are discharged upstream of Hidden Bay at Wollaston Lake. These effluents include toxic levels of: ammonia, sulfates, nitrates, chlorides, phosphates, polyacrylamides; organic solvents (amines, isodecanol and kerosene); heavy metals such as lead, mercury, cadmium, arsenic; and 
radioisotopes such as uranium, radium and radon gas. ${ }^{16}$ However, none of the environmental impact assessments collected baseline background data from known traditional foods or medicinal species. Neither was there any attempt to model or determine cumulative or synergistic environmental threats to biota or Indigenous residents, in particular, traditional resource users (Berman, 1994; Westra, 1998).

Similar toxic effects on the Serpent River First Nation reserve are found in the case of uranium mining at Elliot Lake, Ontario. ${ }^{17}$ An environmental assessment panel of a technical nature, was established to review the decommissioning of four tailings management areas (130 million tonnes of tailings) near Elliot Lake. Public meetings were held on the Serpent River First Nation Reserve in December, 1993 and hearings were held in January, 1996. The panel concluded that tailings present a perpetual environmental hazard, that generate acid and heavy metals including radioactive isotopes, the solubility of which is increased when exposed to acidic conditions. Eighty-five percent of the radioactivity present in the original ore remains in the tailings.

This vast reservoir of contaminants has been deposited adjacent to the upper drainage basin of the Serpent River, eight miles upstream from the Serpent River First Nation Reserve. The Serpent River drains into Lake Huron's North Channel. The panel noted that there are widely divergent views on issues of dose rate, total dose and the

16. Data on toxic effects of various chemicals can be found at the following site: http://www.ec.gc.ca/CEPARegistry/subs_list/Toxicupdate.cfm.

17. Canadian Environmental Assessment Agency (CEAA), Decommissioning of Uranium Mine Tailings Management Areas in the Elliot Lake Area, Supply and Services Canada, Ottawa, Canada, 69 p., June, 1996. 
correlation of these factors with increased risks to human health. They also noted that it was unlikely that there would ever be a fully walk-away, zero-risk solution to containment. Given the nature of the long-term hazards, the panel has set out a number of recommendations that seek to ensure that effective containment is established.

Goldman (1993) reported that Indians on the reserve used untreated water from the Serpent River and suggested that the number of cases (non-fatal) of cancer and genetic effects caused by exposure to ionizing radiation may equal the number of expected cancer deaths. Estimated exposures are 300-3,000 times greater than U.S. criteria for "acceptable risk". The International Joint Commission responsible for the Great Lakes, identified the Serpent River system as the single largest contributor of radioactive pollution to the Great Lakes. It is also believed, by many, that the decline, by one-half, of the population of the Serpent River First Nation Reserve due to emigration, is attributable to cultural displacement due to environmental uncertainties and economic vagaries, itself, a function of uranium mining.

During the review, the Serpent River First Nation reiterated that aside from the loss of access to traditional lands, the environmental impacts of the uranium mining industry has disrupted traditional activities (including socio-psychological effects) and lifestyles. First Nations are particularly concerned about residual effects. Further, First Nations believe these lands should revert to traditional use as they were part of their Aboriginal heritage and the economic hinterland of its subsistence economy. More broadly, First Nations requested economic compensation for past, current and future loss of traditional lands. First Nations also expressed the wish to have a substantial voice in 
decisions on future land use.

\section{Mercury Poisoning in Northern Ontario}

The environmental devastation of the Grassy Narrows and Whitedog Reservations graphically illustrates the effects of toxic racism (Murphy, 1994; Wheatley, 1997; Wheatley et al., 1997). In the 1960s and early 1970s, mercury was discharged from a chlor-alkali plant into the English -Wabigoon river system in Northern Ontario. Grassy Narrows and Whitedog, two Ojibwa communities, depended on fish from the river system for subsistence and as an economic base. Fishing is part of the Ojibwa cultural identity. By 1970, high levels of mercury in fish led to the closure of the commercial and subsistence fisheries. The high levels of methylmercury were subsequently expressed as Minamata disease.

The effects of mercury pollution have contributed significantly to social and cultural impacts such as dislocation, in addition to direct health effects (Shkilnyk, 1995; Wheatley, 1994; Wheatley and Paradis, 1996). Both communities reflect the hopelessness that results from the destruction of a familiar lifestyle, loss of self-esteem and loss of the traditional values of respect, sharing and caring. Even after compensation was paid, social problems persist.

\section{PCB Incineration at Swan Hills Alberta}

The Swan Hills Special Waste Treatment Centre in Northern Alberta was designed for the incineration of special wastes, in particular, PCBs. It is necessary to 
manage PCB waste because it is carcinogenic in parts per hundred thousand to one million. If burned at high enough temperatures, incineration destroys all toxic elements. However, if these temperatures are not reached, incineration produces two other carcinogens, dioxins and furans. Dioxins and furans, though, are much more toxic than PCBs since they are toxic at much lower levels of concentration, i.e. parts per billion.

A malfunction in October 1996 allowed some of the process gases (PCBs, dioxins and furans) to pass directly into the ambient air. Wild game and fish are abundant in the area. This area has been a traditional source of country foods for Aboriginal peoples living in the area (Guidotti et al., 1998). Aboriginal people may have higher rates of consumption of country foods, including medicinal plants, but specific data on consumption patterns for Aboriginal residents was not available nor was it considered (Chen et al., 1998). A food consumption advisory has been issued within a $30 \mathrm{~km}$ radius.

The result of these toxic racist practices is that traditional peoples who consume country foods are exposed to unacceptable toxic loads, leading to disproportionately greater health risks. Usually, the closer one's proximity is to the source of contamination, the greater the environmental burdens or toxic loading. Data from the Special Treatment Centre at Swan Hills, Alberta is applicable here since it clearly demonstrates this dispersion pattern. This suggests that resource users in the immediate vicinity are the most likely to suffer significantly higher exposure levels in both the food chain and via the air, land and watersheds, especially downwind or downstream. Subsequently, these users suffer disproportionately higher health risks or threats. However, long range transport, often trans-boundary, of volatile aerosols such as PCBs, bromides, sulphides 
and agrochemicals, including pesticides and radionucleides, are known to disperse over large areas, subsequently entering the food chain in other jurisdictions (Braune and Simon, 2004; Mallory et al., 2005).

\section{Pulp and Paper Contamination of Water in Northern Alberta and the N.W.T.}

Although the Alberta-Pacific bleached kraft pulp mill (Alpac) claims to be the least polluting operation in the world, its effluents augment toxic loading from the seven existing mills on the Peace, Athabaska and Slave River system. Pollutants extend more than 1,000 kilometres downstream into the Northwest Territories. At the Alpac hearings on pulp and paper production in Northern Alberta conducted by the Alberta government, the Northwest Territorial government expressed concern about toxins entering their jurisdiction. The levels of chlorinated organic compounds found in fish in the Peace, Athabaska and Slave Rivers provided them with cause for concern because Aboriginal peoples in this area consume large quantities of fish, aquatic mammals and birds.

However, rather than deal with the pollution issue, the response of the federal and provincial/territorial governments was to recommend that Aboriginal peoples refrain from eating organ meats, which have the greatest concentration of toxins. Organ meats are considered to be a delicacy and are culturally important to many First Nations. Further, the Canadian government does not take the consumption patterns of natives into account when it sets environmental and health standards for contaminants such as dioxins and furans. It is often more convenient to deny cultural preference, and hence conduct analyses that are racist, e.g. gastronomically Eurocentric, than collect the data necessary 
to make credible decisions on toxic loads. Within this basin catchment area it has been estimated that contaminant loading is ten-fold higher for Indigenous peoples

The effects of toxic racism on the food chain have devastating consequences for First Nations. Gamble (1988) has shown that on average fifty-eight percent or more of the diet of Indigenous residents in northern communities is comprised of country foods. This leaves Indigenous peoples with the choice of consuming contaminated foods with pathogenetic consequences, moving or changing their food consumption habits. As country foods diminish, dietary substitutions usually involve replacement by low cost dietary supplements such as carbohydrates. This has resulted in significant increases in incidence of, for example, diabetes, gall bladder disease, hypertension, cardiovascular disease, obesity, excessive tooth decay, etc.--a perverse form of "neocolonialist dietary assimilation' to be sure. ${ }^{18}$

Moreover, scientists do not have a detailed understanding of bioaccumulation and therefore are limited to quantifying and not examining ecosystem impacts (Goldstick, 1987). This means that they can establish correlations but not causation. Since communities rely on renewable resource harvesting as a mainstay of their local economy contamination of the aquatic (e.g. fish, moose, muskrat, beaver, wild rice, bulrush) and terrestrial (e.g. caribou, Labrador tea, blueberries) ecosystems are nothing short of cultural and biological genocide since the integrity of both resident human populations and the ecosystem are compromised.

${ }^{18}$. Cf. Indian and Northern Affairs Canada http://www.ainc-inac.gc.ca/pr/ra/execs/serv-1_e.html 


\section{Ecosystem Health, Habitat Loss and Overexploitation in Pulp and Paper and}

\section{Hydroelectric Production}

The facet of toxic racism I will briefly explore in this section concerns forestry and hydroelectric development, in particular, the pulp and paper industry, which is a major source of contaminants from bleached kraft pulp mills. Herein, I broadly define ecosystem impairment as a marked decline in ecosystem productivity or sustainability and quality, wherein, human and ecosystem health is diminished or compromised substantively. In the case of pulp and paper production in Northern Alberta, extensive habitat loss is less quantifiable as boundaries are contiguous. Spatial and ecosystem data are also sparse. Hence, most of my assumptions and evidence are qualitative. The geography of scale and pattern of agricultural, forestry, water management, fisheries and, in some instances, mining operations infringe on the carrying capacity of various ecosystems on which local Aboriginal cultures and traditional pursuits subsist.

Since I am concerned with more remote regions of Canada currently being subjected to neocolonialism, my overview is primarily confined to forestry and hydroelectric operations within the boreal region, though the intensity of agriculture and population growth has perhaps exceeded sustainability in some areas such as Southern Alberta (the Oldman River Basin and Pine Coulee Water Management Project), further impairing the last vestiges of intact ecosystems on which local tribes still rely. Here too, I argue that ecosystem impairment such as toxic contamination, often results in economic and cultural displacement of Indigenous populations, along with accompanying 
predictable and sustained deterioration of Aboriginal physical and mental wellness.

The pulp and paper industry produces fifty percent of all waste dumped into Canada's national waters including chlorinated organic compounds (e.g. dioxins and furans) and heavy metals (e.g. mercury). Many of these toxic contaminants also exhibit cumulative and synergistic effects. Most often, it is the limits of technology, not health and environmental considerations, that determine effluent and stack regulations. Here too, the courts thrust jurisdiction upon a reluctant federal government. Despite considerable public and scientific environmental concern (Sherman and Gismondi, 1997) and protests from First Nations including the Lubicon (http://www.lubicon.ca/), directly affected by the Diashowa pulp mill on the same river system, and the Northwest Territorial government, Alberta persisted in granting approval.

The review panel of Alpac which included two Aboriginal members, was established jointly by Alberta and the Federal government to conduct an environmental assessment of the bleached kraft pulp mill proposed by Alberta-Pacific Forest Industries Inc. in the Athabasca region. The review included rail access and two major road systems. Although the proposed mill would be one of the least polluting bleached kraft pulp operations in the world, it was recommended that it not be approved. The panel concluded that there was considerable scientific uncertainty concerning the cumulative effects of effluents, including chlorinated organic compounds (e.g., dioxins and furans) on the aquatic ecosystem of the Athabasca-Peace River System. Effluent loading of toxins from other mills on this system extend more than $1,000 \mathrm{~km}$ downstream into the 
Northwest Territories. ${ }^{19}$

The majority of the public expressed concern about the high degree of uncertainty with respect to cumulative impacts and degree of sustainability. In fact, the position of the Northwest Territories throughout the hearings was that the current levels of chlorinated organic compounds found in fish in the Peace, Athabaska and Slave Rivers provided cause for concern. Although the panel was to address timber harvesting on Indian reserve lands, they were not to address the proposed Forest Management Agreement (FMA) between Alberta-Pacific and the Alberta government.

This forest management area is also the subject of unresolved land claims. Indigenous peoples fear massive areas may be removed from claims if FMA areas are deemed by governments to be 'occupied' or 'third party interest lands'. Aboriginal peoples questioned the mill approval process, environmental, economic and social impacts, the denigration of their traditional value systems and the effects of this and other projects on existing treaties and pending land claims. A majority of northern Aboriginal peoples who made presentations, were opposed to the proposed forestry project for cultural, environmental and economic reasons. Ultimately, the project was approved by Alberta's provincial cabinet in 1990 despite considerable public and scientific environmental concern (Sherman and Gismondi, 1997).

Of equal or greater significance is the fact CEAA legislation does not bind the provinces, nor are recommendations to protect the environment mandatory. Instead the

19 . Federal Environmental Assessment Review Office (FEARO), The Proposed Alberta-Pacific Pulp Mill, Supply and Services Canada, Ottawa, Canada, 125 p., March, 1990. 
review panel or arbiter's recommendations can be ignored by the proponent or legislative authority. This was the circumstance with the Oldman River Dam where the Province of Alberta continued with construction regardless of a court-ordered review and the eventual panel recommendations that the project not proceed. An environmental assessment of the Oldman River Dam was not proposed by either Alberta or the Canadian government due to jurisdictional wrangling until the Federal Court of Appeal referred the project for public review in March, 1990. This required that federal authorities comply with the Environmental Assessment and Review Process Guidelines Order.

The project was completed in 1991 by the Alberta government during the review. The Alberta government did not formally participate in the review process. The Supreme Court of Canada upheld the Federal Court of Appeals decision (Friends of the Oldman River Society v. Canada (Minister of Transport), [1992] 1 S.C.R.3.). It was determined that the Crown in right of the Minister of Transport (Navigable Waters Protection Act, R.S.C., 1985, c. N-22, s. 5) and Minister of Fisheries and Oceans (Fisheries Act, R.S.C., 1985, c. F-14, ss. 35, 37) must comply with the guideline order (Department of the Environment Act, R.S.C., 1985, c. E-10, ss. 4(1)(a), \%(a)(ii),6)). Federal authorities also had a legal duty to protect Aboriginal interests.

The panel found that the dam would result in substantial environmental, social and economic costs being born by the Peigan Indian Band and recommended decommissioning of the dam. In the event the dam is not decommissioned, the panel recommended the establishment of a negotiating process by which the proponent, the Alberta government, and the Peigan can reach an agreement on mitigation and 
compensation for environmental, social and cultural impacts. This process was ultimately imposed on the Peigan. The panel itself concluded that the failure of the proponent and the Peigan to come to terms over this project is one of the most significant and unacceptable features of the project. Subsequently, another project affecting the same watershed was proposed. ${ }^{20}$

Hydroelectric development in Manitoba has also resulted in massive habitat loss because of flooding. ${ }^{21}$ The Manitoba Northern Flood Agreement was signed in December 1977 by Canada, the province of Manitoba, Manitoba Hydro and the Northern Flood Committee, Inc. on behalf of Cross Lake, York Factory, Nelson House and Split Lake Cree First Nations and the Norway House Cree Nation. The agreement was to specifically address the adverse impacts of the Lake Winnipeg Regulation Project and the Nelson River Diversion Project. These projects resulted in the flooding of 4,800 hectares of reserve land and 212,460 hectares of land traditionally used by these First Nations.

As is often the case, the issue of Aboriginal rights and claims and the roles and responsibilities of the signatories, were not clearly addressed (La Duke, 1993). This resulted in little or no progress on the implementation of shared obligations if identified at all. As a result, the four parties negotiated a proposed basis of settlement as a means of addressing outstanding claims and obligations and to provide a platform for negotiations. Four out of five First Nations, excluding Cross Lake, have successfully negotiated

${ }^{20}$. Federal Environmental Assessment Review Office (FEARO), Oldman River Dam, Supply and Services Canada, Ottawa, Canada, 56 p., 1992.

21. Manitoba Northern Flood Agreement, (December, 1977). 
settlement agreements, which have been subsequently enacted in both provincial and federal legislation, for example, Bill C-14. ${ }^{22}$ One should note here, however, that the development has been in operation for almost twenty-three years, with few recognizable benefits to Aboriginal peoples. These agreements address the rights of treatied Aboriginal peoples but currently ignore the rights of non-status Indians and Metis.

Habitat loss as it relates to forestry and impoundments have devastating effects on traditional resource harvesters, community economic viability and environmental health. The clear cutting and flooding of hundreds if not thousands of square kilometres of traditional lands by multinational conglomerates (e.g. Alpac, Diashowa Pulp Mill, Celgar Expansion, etc.) and/or Crown corporations (Manitoba and Quebec Hydro) regardless of Aboriginal resource use, targets Indigenous lands, economies and resources disproportionately, providing compelling evidence of environmental racism. This results in higher adverse environmental effects being shouldered by Indigenous Canadians (Gareis-Smith, 1994).

Habitat loss in this order of magnitude results in tangible harm and victimization of Aboriginal communities. Penz (1996) argues that "environmental victims refer to people who are or have been harmed by processes that emanate from the natural environment, are mediated by it, or impair access to it, without being compensated for such harm". In such cases, human action or responsibility is implicated and harm is

\footnotetext{
22. Manitoba Claim Settlements Implementation Act, An Act Respecting an Agreement with the Norway House Cree Nation for the Settlement of Matters Arising from the Flooding of Land, and Respecting the Establishment of Certain Reserves in the Province of Manitoba, 48-49 Elizabeth II, 19992000 .
} 
interpreted more broadly than 'a negative mental or physical health outcome'. 'Harm' is thus expanded to include injury to livelihood and environmental displacement without adequate compensation. Indigenous peoples have been referred to as "third party environmental victims"/innocent bystanders, because unlike first party victims of environmental pollution they frequently do not receive the benefits of jobs, salary and profits. Avoidance of liability leads to failures to prevent or redress victimization (Williams, 1996). Environmental victims are often, in effect, sacrificed (non-consensual) for the benefit of a more powerful entity, either politically or economically.

\section{Noise Pollution: Military Low-Flying in Quebec and Labrador}

Noise pollution caused by military low-flying in Northern Quebec and Labrador also has toxic racist effects. ${ }^{23}$ This venue produces tangible environmental harm and victimizes First Nations after a fashion. Similar low flying activities occur at Cold Lake, Alberta. Some 6,000-7,000 low-level training flights (150-300 metres) are currently being conducted out of Canadian Forces Base (CFB) Goose Bay, Labrador, over designated areas of Labrador and Quebec that total $100,000 \mathrm{~km}^{2}$. The Department of National Defense (DND) proposes to increase training flights to a maximum of 18,000 (of which 15,000 would be low-level), to extend the flying season, to add an additional target practice area $\left(300 \mathrm{~km}^{2}\right)$ and to change the designated flight area. In the past DND did not seek First Nations' approval.

\footnotetext{
23. Canadian Environmental Assessment Agency (CEAA), Military Flying Activities in Labrador and Quebec, Supply and Services Canada, Ottawa, Canada, 92 p., February, 1995.
} 
The environmental assessment panel (primarily technical appointees) was given the mandate to examine the environmental, social and economic effects of the existing and proposed training activities. The project entails no extraction of products from the land and little alteration of the physical landscape. There was no mention of aerial fuel dumping. Impacts on the land are mainly from noise and associated startle effects from low-flying aircraft (e.g. sonic booms). Interruption of the reproductive capacity of caribou by the increased occurrence of miscarriages due to the startle effect caused by low flying aircraft as may be occurring in Labrador.

There is a perception held by Aboriginal groups that the project negatively influences their land claims negotiations. In as much, several First Nations communities refused to participate in panel hearings. The panel did note, however, that settlement of outstanding land claims would encourage an open dialogue with Aboriginal communities and promote significant bridge-building. It was also noted that after fourteen years of low-level military flying, there is still considerable scientific uncertainty on the effects of low-level flying on human health, wildlife and the environment as base-line data is sparse or non-existent. The panel contends that this state of ignorance should not be allowed to continue.

The similarities between noise pollution and toxic racism/ecosystem health almost always include: activities that encroach on Indigenous lands; rarely offer culturally appropriate compensation; ignore Indigenous rights as Peoples, and have a significant impact on ecosystem dynamics and health including fecundity, or productivity and environmental quality. Noise pollution is problematic and provides further evidence of 
the existence of new forms of environmental racism.

\section{Electromagnetic Radiation from High Voltage Transmission Lines}

The last example of toxic racism I wish to note is the effect of electromagnetic radiation from high voltage transmission lines, which may be genotoxic and have tentative links to cancer (Baldwin and Preston-Martin, 2004; Habash et al., 2003). At least in one instance, which has an international element, Canada and the U.S., the Lac Courte Oreilles Band of Lake Superior Chippewa, Wisconsin, contend that exposure of band members to extremely low frequencies near the east end of their reservation near Clam Lake may account for inordinately high cancer rates. If correct, locating a second transmission line as proposed by Manito Hydro, on the reserve would compound the problem and inordinately victimize this community even further.

The positioning of hydro corridors could be construed as environmental racism if placement on or near Indigenous lands leads to discriminatory environmental outcomes, i.e., if electromagnetic radiation is shown to cause serious or irreversible damage. This suggests that, as of yet, governments and multinational corporations still do not follow the 'precautionary principle' within the sustainable development model and expose Indigenous peoples and the environment to unnecessary risks. In Canada, both the placement of hydro corridors and the effects of electromagnetic radiation on ecosystem health have not been scrutinized. One would expect, however, that even though the evidence is more circumstantial than absolute at the moment, that governments would tend to err on the side of caution. This also seems to suggest that provinces with 
considerable hydro potential such as Manitoba and Quebec may be more inclined to target remote communities who are less likely to be heard.

\section{The Mortifying Effects of Toxic Racism}

Almost without exception, there has been a communal sense of injustice and anger expressed by Saskatchewan's Indigenous peoples, caused by the extraction of resources worth billions of dollars from traditional lands without due regard for Indigenous economies and societies and the environment. For example, many Indigenous peoples in Saskatchewan are struggling to meet basic needs. Less apparent are the long term environmental and social costs experienced by northern and rural Aboriginal communities.

Toxic racism, however, has broader effects, given the imbrications of sociological systems in ecological systems. In the case of uranium mines near Wollaston Lake, Saskatchewan, workers and Aboriginal communities adjacent to mines are regularly exposed to toxins through deliberate releases, spills and leakages into the watershed, soils, air and food chain (Dudka and Miller, 1999; Goldman, 1993). This makes exposure, in some instances, thrice deadly: one can be exposed as a miner, as a resident, as a consumer of country foods or, by a combination of all three. Studies conducted at Cumberland House, several hundred kilometres southwest of Wollaston Lake, provide compelling evidence that locally high rates of arthritis and kidney disease are caused by airborne by-products of uranium mining (Muldrew, 1996). In the U.S., children growing up in uranium mining areas developed ovarian and testicular cancer in the order of 15 
times the national average (Taliman, 1992). Most uranium mining in the U.S. is confined to Aboriginal lands. Within the Elliot Lake/North Shore area, or Serpent River basin, cancer mortality rates for residents were estimated to be from 7,000 to 12,000 times higher than those of northern hemispheric populations as a whole. The range or incidence for the former, northern hemispheric populations are from three to fifty per hundredthousand (Goldman, 1993).

The exposures at Elliot Lake before capping were 300 to 3,000 times greater than the U.S. criteria for acceptable risk. If Goldman's figures are accurate, cancer deaths could be as high as seven to twelve per hundred over the long-term. This circumstance is indicative of genocide or apartheid given the exposure of resident Indigenous peoples to significant toxic loads that may be causing serious bodily and/or mental harm. In addition, the number of cases of non-fatal cancer and genetic defects caused by exposure to ionizing radiation is often equal to the number of expected cancer deaths.

Recent studies also suggest that exposure to other hazardous chemicals such as heavy metals may lead to a variety of non-cancer endpoints even at low concentrations (Carpenter, 1998). Exposure to low concentrations of toxic chemicals cause irreversible effects on human embryos and very young children, possibly influencing intelligence, attention span, sexual development and immune function, disrupting the endocrine systems (e.g. hypothyroidism) and have direct effects on the brain and other organ systems. These effects are subtle and difficult to quantify. Goldman (1993) suggests the incidence of cancer is likely higher in Saskatchewan because ore grades are much higher and containment is much more difficult. 
This leads one to conclude that negative social, cultural, economic and environmental impacts contributing to environmental racism, are more extensive and intensive for traditional resource users. One can plausibly presuppose that for Indigenous peoples, especially primary resource users, there are direct links between environmental degradation and cultural displacement and physical, social and cultural harm, i.e., 'actual adverse effects causing loss, injury or some other form of danger/hazard' (Mehta, 1995). These are distinct from indirect toxic effects normally associated with exposure in other victims e.g. intergenerational exposure. For example, intergeneration environmental racism follows as a consequence of the parent being differentially exposed to cumulative hazardous substances, that may, in the future, cause injury. This jeopardizes the needs of future generations or what is also referred to as intergenerational equity. In the first instance of traditional resource users, one can document tangible harm in the present; while in the second instance, the intergenerational instance, one tries to predict possible harm that may occur in susceptible target populations (cf. Johnson et al., 1999; Perera et al., 1990 re: fetal development ). In this regard, 'sustainability and equity are two sides of the same coin' (Rees, 1991).

\section{The State, Economic Development and Toxic Racism}

The state plays a constitutive role in toxic racism since its regulatory mechanisms are geared toward capitalist economic development. The economic development that has taken place though, distributes rewards and risks in a grossly unequal fashion: economic rewards accrue to corporations and the state; destruction, devastation and displacement to 
Indigenous peoples. At the same time however, since governments themselves are both the regulators and profiteers through royalties and taxes, their political, regulatory and economic motives are often biased or complacent. State actions also serve to fortify the 'difference' of Aboriginals.

Indigenous peoples, as wards of the state, rarely have the political power or social resources to defend themselves against these kinds of toxic encroachment. Often, the limitations of technology are predictable and provide a licence for industry to pollute, albeit at a somewhat regulated or controlled level, if measurably enforced. These environmental practices would seem to condone 'toxic racism', i.e., the biophysical and sociological impairment of ecosystem functions producing social disorder and stifling democratic processes.

Moreover, provincial economic diversification programs have not only provided the infrastructure necessary for exploitation by venture capital corporations but have provided direct investment (Muldrew, 1996), subsidies and tax incentives (Goldstick, 1987). For example, the Saskatchewan government has made it abundantly clear that they will not tolerate anything that might harm the investment climate (Dobbins in ICUC \& NNRC, 1984). Saskatchewan has even gone as far as entering a stay of proceedings, thus preventing judicial review of the uranium industry (Goldstick, 1987). This provides further evidence that the Saskatchewan government and its agencies are in "conflict of interest" with respect to the public trust, are at odds with the letter of the law (O'Connor, 1993), and have failed to recognize and factor in the adverse social and ecological costs these megaprojects have on Aboriginal residents. The resulting environmental and social 
consequences of these policies and practices serve to sustain the toxic effects of environmental racism. They do so by excluding First Nations from crucial decisionmaking processes, actively suppressing their power, exploiting their lands and destroying their capacity to sustain their way of life. The cases discussed above illustrate the pernicious nature of the state-capital relation in this regard.

For example, the CEAA review of uranium mining in Saskatchewan noted that certain federal-provincial jurisdictional ambiguities continue to exist such as the inability of either jurisdiction to prosecute or to enforce workplace safety infractions. They noted that only a small fraction of northerners will economically benefit from uranium mining. Neither will they experience a noticeable improvement in standard of living unless some form of revenue sharing is introduced. It was recommended that a fiscal table be established, permitting tripartite negotiations (which includes revenue sharing) between Saskatchewan, Canada and FSIN (Federation of Saskatchewan Indian Nations).

There is a communal sense of injustice and anger caused by the extraction of resources worth billions of dollars from traditional lands where many are struggling to meet basic needs. Revenue sharing needs to encompass all northern resource extraction activities and be redistributed proportionately to all affected First Nations, including Metis and non-status Indian residents, if equity is to be achieved. The Prince Albert Grand Council (northern component of FSIN), specifically expressed its dissatisfaction with the advisory (versus active) role given northerners with respect to environmental issues, referring to these as totally inadequate. In fact, Aboriginal peoples want to be recognized as a third order of government in the management of their resources and local 
economies. Only recently (1997) were a number of initiatives, including cumulative environmental effects (e.g. socioeconomic and health impacts database for northern communities), baseline community health status survey, epidemiological studies, and the possible contamination of country foods, undertaken to monitor different aspects of community and worker health.

Massive disruption of ecosystem dynamics by multinational conglomerates has also occurred in the forestry industry. Corporations have been given exclusive clear cutting and planting (usually monoculture) rights and Crown corporations with similar water management rights, regardless of Indigenous claims, contribute significantly to the loss of First Nations' renewable resource economies, subsequently diminishing community cohesion, which in turn, culminates in both physical and psychological harm (Jhappan, 1992; La Duke 1993).

As concerns environmental regulatory mechanisms, older, more polluting mills, not unlike the one at Celgar, British Columbia, are grandfathered and not subjected to more environmentally friendly legislation. ${ }^{24}$ For example, the modernization of the bleached kraft mill at Castlegar was viewed by the Province of British Columbia as an opportunity to impose current government pollution standards and controls on this mill. These aimed to reduce excessive toxic emissions and effluent discharges into the environment. Prior to this proposal, inordinately high pollution indices were permitted by provincial and federal legislation under a thirty-year-old variance, or what is frequently

\footnotetext{
24 . Federal Environmental Assessment Review Office (FEARO), Celgar Expansion Review Panel Final Report, Supply and Services Canada, Ottawa, Canada, 111 p., February, 1991.
} 
referred to as a grandfathering clause. The impacts of the project on the management of provincial forests were excluded.

However, Indigenous peoples contend that forestry operations impinge on Aboriginal rights. Beyond these narrowly defined biophysical considerations, the Panel was not to consider Indigenous claims to the land and resources, in particular, cutting rights, extended to Celgar and its affiliates. Nor were they to consider the environmental, economic, social or cultural impacts experienced by Indigenous communities, for example, the cumulative impact of toxic effluents (e.g. chlorinated organic compounds) and emissions on Aboriginal health and the renewable resource economy. Again, Aboriginal environmental concerns were ignored or given little credence within this exercise. These grandfathered mills do not have to comply with current standards, therefore effluent loading of toxins are many orders of magnitude higher. Also from a legal perspective, it is highly unlikely that grandfathered mills will be held accountable for their actions since legal liability may not exist or apply. This suggests that both the federal and provincial governments often tolerate routine practices (industry standards) that discriminate against Indigenous peoples by placing their health and the environment at risk.

One last case, that of the Canadian National Railway development in British Columbia, illustrates the destruction and displacement of state-supported capitalist development visited on First Nations. ${ }^{25}$ The specific issue dealt with in the Fraser-

25. Fraser-Thompson Corridor Review. Federal Environmental Assessment Review Office (FEARO), Fraser-Thompson Corridor Review, Supply and Services Canada, Ottawa, Canada, 52 p., January, 1986. 
Thompson Corridor Review, was directed towards the twinning of the Canadian National railway in the Rocky Mountains but takes on a broader perspective when one considers all encroachments including other railway lines (Canadian Pacific), highways, transmission lines and pipelines, which subsequently fragment the bottom lands. Bottomlands serve as transport corridors in alpine areas. Some sixty reserves are confined to these valleys and occupy some fifty percent of habitable/developmental lands. These lands also have moderate to high heritage potential. Aboriginal peoples see this as a cultural intrusion by industry on river ecosystems, in particular, bottom lands, which further impair resources and traditional pursuits. Many Indigenous peoples also argued that construction should not be allowed to proceed until claims are settled.

Generally, both exploitive non-renewable and renewable resource development and industrialization involving venture capital, results in serious environmental harm and disruptive, negative and subordinating sociopolitical and socioeconomic effects on Aboriginal peoples. For example, Goldman (1993) reports that nearly one half of the Serpent River band has had no other option but to relocate for social reasons, including environmental and economic ones. In part, physical displacement was a function of shrinkage of the band's economic and cultural base or holdings and deterioration of environmental productivity and quality. Environmental quality includes the exposure to significant levels of toxins and associated life-threatening health risks beyond that experienced by the general public (toxic displacement). Health standards for contaminants are set for the "average white Canadian male", not for high risk populations or "special populations" such as Native Canadians (Richardson et al., 1993). This allows 
both industry and governments to distort the devastation and risks through statistical rigging.

In all of these case of toxic racism, as a component of environmental racism, Natives report that serious environmental and social impacts have occurred, despite assurances to the contrary from government and industry. Thus, in sum, by examining these data, it is plausible to conclude that the destruction of ecosystem diversity and population dynamics will lead to the displacement of Indigenous peoples (e.g. Serpent River Band) or forced cultural and economic dependency. Usually within these communities negative impacts are only indirectly quantifiable through tabulating disparate impacts that affect community social stability and health. Health is a dynamic process involving the harmony of physical, mental, emotional, social, environmental and spiritual well-being. For most First Nations, health is directly connected to community vitality. Under the current environmentally racist regime, for Aboriginal residents, costs tend to outweigh benefits (Harding, 1988).

\section{Toxic Contaminants and Risk}

When considering the extent of environmental and disparate environmental impacts on First Nations, it is important to consider 'risk'. This is because it is 'how we determine environmental risk' and 'how we act on it' that in large measure determines whether treatment is equitable and just and/or fosters environmental and social inequity. Toxic contaminants are not well understood and the long term and chronic effects are often ignored (Seth and Mackay 1999). This implies that the very foundations of risk 
logic, and its correlate in the precautionary principles, are being subverted or suspended in Canada. It is crucial to note that risk concerns more than the calculation of possible costs and benefits; rather, it is a theoretical mechanism for weighing different sets of values and political orientations (Mehta, 1995). Thus, various cultural, including dissimilar risk perceptions, and environmental, political and economic factors, influence risk and change outcomes (Vaughan and Nordenstam, 1991). As concerns toxic racism, risks appear greater when they are perceived to be unfairly shared, are imposed on individuals, are not easily controlled, or are linked to man-made hazards. For example, there are no assurances that uranium mines can operate without exceeding pollution limits, since tailings retain eighty-five percent of the radioactivity of the original ore and associated heavy metals. Neither are there any assurances that they can be secured to prevent the spread of contamination. Thus, risk assessment of toxicity as concerns environmental racism is intimately linked with the political struggles of First Nations in Canada.

Presently, in Canada, risk analysis fails to consider environmental and social costs, including equity. Risk assessment frequently involves conflicts or trade-offs between values and is inherently political. The Canadian Cabinet Directive on the Environmental Assessment of Policy, Plan and Program Proposals (1999) offers ample evidence of the failure of risk analysis to accommodate equitable considerations (http://www.ceaa.gc.ca/016/index e.htm). All too often, wealth or economic considerations are given priority over a healthy, sustainable environment. This is often referred to as 'the human-capital approach'. Risk assessment frequently ignores the 
social-class distribution of risk and social inequalities of risk exposure and instead becomes an exercise in moral posturing and domination.

In societies with residual risk analysis, body counting replaces social and cultural values and science often hovers blindly above the boundary of uncontrollable threats (Dembo et al., 1990). Within residual risk societies, those who control the discourse on risk often control the political values, information flow, power and political influence while excluding others. Because of these social, environmental, political and cultural inequities, disenfranchised groups are frequently victimized. Environmental risk policies, procedures and legislation must be modified to accommodate the life-style and beliefs characteristics of First Nations, and identify and correct areas that cause disproportionately high and adverse environmental health effects and discriminatory environmental outcomes.

\section{Conclusion}

While some may argue that environmental degradation occurs at the cost of a few and for the benefit of many, the reality is that laws regarding human and civil rights and environmental protection are enforced on a selective basis (Johnston, 1994). In the past, the UN Human Rights Committee upheld and upbraided the federal government for human violations under section 27 of the Covenant (Jhappan 1992) with respect to oil and gas development on Lubicon lands in Alberta. These violations still persist fifteen years later, and are further aggravated, for example, by forestry development. It has been suggested that section 27 of the Covenant and the Draft Declaration of Principles on 
Human Rights and the Environment, which includes the universal human right to a 'safe and secure, healthy and ecologically sound environment' equally applies to all violations of Aboriginal environmental rights (Sachs, 1996). Accordingly, interventions need to occur when a state inflicts serious bodily or mental harm upon members of a racial group or groups. However, this sort of intervention, such as the later involving the Lubicon, is a rarity.

An exploitative market economy often promotes present-day security for states in the face of an open-ended uncertain future for those that bear the brunt of pollution, in this instance, Aboriginal peoples. Efforts to maximize corporate wealth often lead to First Nations experiencing a disproportionate amount of environmental burdens and discriminatory environmental outcomes. The exploitative market economy, accelerated by globalization, is motivated by profit at the expense of the environment and local economies. Primary resource extraction, usually associated with multinational corporations, as outlined above, is the most destructive component of industrialization due to the scale and extent of damage. These environmental impacts are associated with large geographic areas or, macro-impacts.

Resource extraction frequently displaces or negatively impacts lands and resources belonging to Indigenous peoples. Since the productivity and quality of their environment is diminished and sustainability compromised, this creates an environmental as well as moral dilemma. Extraterritorial resource extraction including the offshore adjacent to Aboriginal communities and lands, is often accomplished without due regard for Indigenous biophysical and sociological systems. This is further amplified through 
cumulative and synergistic impacts as a result of multiple development activities.

Generally, chronic emissions of toxins and environmental threats such as commercial overharvesting are spread over long periods of time, and cause and effect are difficult to prove. However, it is evident from the contextual data provided above, that toxic burdens or threats, in conjunction with exclusionary environmental, political, economic and social forces, disproportionately impact or displace Indigenous renewable resource-based economies. Persistent degradation of Aboriginal lands and resources further erodes and denigrates Indigenous environmental and human rights and creates uneven geographies of poverty. This circumstance highlights the on-going failure by many Canadians and state governments to recognize or acknowledge that these predictable distributional impacts or burdens are exclusionary and racist in nature, valueladen and socially-embedded. Toxic racism, as a key component of the environmental racism analytic developed herein, provides further corroborating evidence that neocolonialism--displacement by environmental means--persists with respect to Aboriginal peoples.

In the next chapter, I address how the assertion of First Nations sovereignty, that receives its justification through the human rights to self-determination, provides a viable avenue for redressing the adverse effects of environmental racism by the Canadian state. Doing so, I contend, may assist in the struggle for First Nations' rights to security of person and the right of self-determination, each of which have been substantially threatened in Canada. 


\section{Chapter 5: Aboriginal Sovereignty and}

\section{Environmental Racism Discourse}

\section{Introduction}

Current environmental racism and justice theory has not fully addressed Aboriginal environmental issues. Instead, environmental justice theory has concentrated on civil rights and race discourse associated with ethnic minority rights and has ignored Aboriginal environmental rights associated with issues of 'peoples' and nations. The expanded environmental racism analytic revisits the juridical and territorial practices of the state. It does so by questioning the very nature of the founding actions on which state sovereignty is based, encouraging legal advocacy to decentralize, diversify and democratize the state. Doing so, I contend, requires affirming First Nations sovereignty as a primary means for redressing the adverse biophysical and sociological effects of environmental racism perpetrated and supported by the Canadian state.

It has been suggested that Aboriginal environmental justice can only be achieved through formal legal recognition or return of Indigenous 'sovereign' authority through which these communities can negotiate, construct and protect political authority and cultural autonomy (Delora, 1989; Macklem, 1992/93; Macklem, 1995). Generally, 'autonomy' is a social phenomenon resulting from relations of cooperation and attitudes of mutual respect (Frankenfeld, 1992). In the case of Indigenous peoples, the environmental racism analytic must address environmental, economic, political and 
territorial rights normally associated with some degree of 'sovereignty'. As such, this requires confronting the notion of sovereignty with respect to Indigenous peoples, in order to provide a distinctive, critical and analytical assessment of its relevance to environmental racism. By examining, new avenues of resistance through the affirmation and assertion of sovereignty and environmental justice discourse, it is possible to expose the on-going oppression resulting from neocolonialism experienced by Aboriginals. My intention here is to help widen the environmental political agenda and at the same time provide more scope and legitimacy to Aboriginal claims.

Both human rights discourse and the historical conventions of the recognition of sovereignty, as contained in treaties, provide means of transformation. Human rights discourse, as part of the expanded concept of environmental racism developed in this thesis, provides the normative basis for showing the illegitimacy of Canadian state actions, legislation and processes that are racist and neocolonialist in their ideology, practices and effects. The contradictory positions of the Canadian state on First Nations sovereignty concerning the interpretation of treaties can also be deployed to produce positive outcomes.

Aboriginal Canadians persist in their contention that they retain sovereign powers - i.e. control - over reserve lands and lay claim to extraterritorial rights. These include: hunting, trapping and gathering areas, fishing (including marine resources), burial grounds, sacred lands, meeting grounds and timber tracts (Goldstick, 1987) and, to some degree, subsurface rights and development rights within the confines of traditional holdings. Subsurface rights include those dealing with mining and mineral exploration, 
oil and gas development and development rights include those dealing with a stake in tourism, outfitting, road construction and Crown land leasing.

The analytic of environmental racism provides a means to resolve the impasses faced by First Nations when faced with racist state practices premised on the arrogation of sovereignty to the Canadian state alone. As shown above, the Canadian state excludes Indigenous peoples from legislation and process, thus institutionalizing racism and producing devastation, destruction and displacement through toxic racism. In contrast to statist process, human rights discourse is external to state claims of legitimacy in their treatment of First Nations. As such, claiming the right to sovereignty on the basis of human rights provides a point of leverage for First Nations. Human rights discourse supports the claims of sovereignty of First Nations. First Nations have a right to economic and social self-sufficiency (Fisher, 1995; Guay, 1995), not apartheid style homelands (Jeffreys, 1994).

\section{Analytical Context}

In order to situate the debate about sovereignty, it is necessary to examine social, cultural, political, legal, environmental and economic issues in multiple venues. This is a necessary step for developing the strategies and tactics of resistance and transformation. Much of the scholarly writings on environmental justice and its corollary, environmental racism, do not adequately address the complexity or depth of the interplay between the biophysical realm and social environment (Yamamoto and Lyman, 2001). This is particularly true of matters of power and consent. Subsequently, many assumptions are 
left unexplored and untested, such as the environmentally exploitive and exclusionary practices of the state, contributing to the marginalization of Aboriginal societies within Canada. Sovereignty, as we know it, is primarily a state construct that has served to set the legal boundaries for international relations. Since the rights of environmental protection, self-determination and sovereignty have never been, and are not now, fixed in concrete legal doctrine, these concepts and their applications are continually evolving conceptually and experimentally in response to the pressures of events, and to the prevailing moral and political climate (Falk, 2000). The environmental racism analytic does not annul or diminish state sovereignty, rather it transforms and qualifies it through reconfiguration and renegotiation (Held, 1989).

\section{First Nations and Sovereignty: The Canadian Pattern}

In Canada, the act of union excluded First Nations in its constitutional foundation and yet the existence of treaties between the Crown and Indigenous peoples implies that a confederal arrangement existed. That said, rather then addressing Aboriginal sovereignty in a fair and equitable manner, the founding fathers adopted a distinctly Eurocentric bent in defining constitutional governance and law and simply excluded First Nations from the discourse. Treaties are a form of political recognition, implying a measure of consensual distribution of power. However, the matter of the sovereignty of Aboriginals as peoples/nations persists. In this respect, First Nations can be considered to be, at a minimum, 'collectivities', entitled to and requiring self-determination, united by objective (history, language, culture) and subjective (connectiveness) bonds, and hence, groups 
rights (Macklem, 1992/93). And, from a sociological point of view, they qualify as 'nations' and 'peoples'. They are so in the sense of being historical communities, more or less institutionally complete, occupying a given territory or homeland and sharing a distinct language and culture (Macklem, 1992/93; Kymlicka, 1996). Recently, Canadian courts are increasingly recognizing Aboriginal collectivities/groups as political communities or nations with as yet undefined (by the courts) sovereign rights (Berger, 1977; Kapshesit and Klippenstein, 1991). Legislation, such as the Canadian Charter of Rights and Freedoms, also recognizes and supports this notion of group rights.

\section{Human Rights, Self-Determination and Sovereignty}

Many Aboriginal people see sovereignty as a human right with international dimensions attributable to 'peoples' rather than simply being a state matter of citizenship or civil rights (cf. Santos, 1995; RCAP, 1997). Early environmental racism discourse, not unlike distributive justice discourse, primarily targeted the inequitable distribution of disparate impacts under the auspices of civil rights. Civil rights discourse, however, failed to address the broader issues of self-determination and actionable rights, due Indigenous peoples. Similar conclusions can be drawn with respect to citizen rights, which appear to be equally capricious (Hirst and Thompson, 1995). According to the Universal Declaration of Human Rights, human rights are abused when political and economic institutions and processes wrest control over traditionally held resources from Indigenous peoples without negotiation or compensation (http://www.un.org/Overview/rights.html). A human rights based discourse, goes beyond state boundaries and subjects the state to 
external scrutiny of a higher normative order. This provides means for challenging and redressing the adverse effects of environmental racism faced by First Nations.

A human rights-based paradigm recognizes that environmental racism not only injures its victims but also violates their fundamental rights. Inclusion of an environmental human rights regime further exposes pretentious or false claims by states to exclusive dominion. It does so through its ability to diminish so-called exclusive state jurisdiction over human rights and environmental law by subjecting nation states to external scrutiny. Thus, addressing sovereignty within environmental racism discourse will serve to provide broader legal and moral foundations to Indigenous claims of modern-day environmental neocolonialism. Human rights also speak to the right to a safe environment, political participation, freedom from violence, due process of law, education and adequate nutrition. International human rights has increasingly emphasized the rule of law and due process of law and substantive rights like self determination, rather than procedural rights.

Subsequent declarations such as the International Covenant on Economic, Social and Cultural Rights, Article 25, Universal Declaration on Rights of Indigenous people and Rio Declaration: United Nations Conference on Environment and Development, 1992 further acknowledge and entrench these rights (cf. Brundtland Report: World Commission on Environment and Development, 1987). Summaries of other relevant conventions and their implications are provided by Kastrup (1997) and Freeman (1995). International bodies have increasingly recognized that another legitimate human right exists which combines issues of self-determination along with the accompanying 
derivative rights of social justice and environmental rights. Jointly, these rights have been referred to as 'environmental human rights' (Popovic, 1996). Some of the basic tenets of environmental human rights include: the inherent right of all 'peoples', including Indigenous peoples, irrespective of state, to enjoy and utilize fully and freely their national wealth and resources, and the concurrent right to a clean and safe environment. Development of these rights are in their formative stages but increasingly are acquiring broader, legal and moral foundations. Environmental human rights discourse combined with environmental racism discourse, thus provides Indigenous peoples with another venue in which to press claims of state injustice.

For the purposes of this thesis, I take self-determination to mean the domestic expression of political entitlement stemming from sovereign rights. These rights include the right of political and institutional autonomy and some measure of derivative rights to development. Self-determination is an expression of international and national rights. Self-determination refers to the right of an Aboriginal nation to choose how and by what means it will be governed. Self-determination thus is not an ethnic right, but rather is a fundamental right of 'peoples'. These rights do not impart a legal nor moral right to secede from a 'state'. Rather, the right of self-determination can be expressed in this context as the right to exercise limited sovereignty (Spaulding, 1997). This is not unlike Macklem's definition, which portrays self-government as a domestic constitutional expression of the normative ideal of self-determination in which 'peoples' have the right to determine freely their political status and pursue environmental, economic, social and cultural development somewhat independent of state interference. Self-government flows 
from the principle of self-determination. Self-government is one frequent outcome of the exercise of the right of self-determination and refers to the right of peoples to exercise political autonomy. Self-government is one possible result of that choice.

As Spaulding has noted, "In Canada, the form of political organization most Aboriginal rights holders would prefer, divides the governing mandate between Canadian, Provincial and Aboriginal polities. The right of self-determination can be expressed in this context as the right to exercise limited sovereignty" (Spaulding, 1997). Self-determination can be construed as placing Aboriginal peoples in the position of being both independent and equal sovereigns. Thus, First Nation communities differ from other Canadians in their relationships to land, traditions of tenure, economic organization and level of affluence. For instance, Indigenous peoples argue that agreements with the Crown, as well as constitutional and legal agreements and hence recognition, demonstrate that they were historically independent and equal in nation building. This represents another key to institutional implementation of human rights in the service of democracy as well as environmental and social sustainability. Yet, state governments continually attempt to control traditionally-held land and resources belonging to Indigenous peoples. However, Indigenous peoples are the original landlords, and as such have the right, according to conventions of sovereign agreements between 'nations' or 'states', to govern their own resources.

The failure of the Canadian state to acknowledge First Nations' sovereignty and right to self-determination in its hegemonic processes and practices is a key facet of its virulent state racism. Moreover, it amounts to an apartheid process. To reiterate what we 
said in Chapter 2, the International Convention on the Suppression and Punishment of the Crime of Apartheid, Article II, defines 'apartheid' as:

- the denial to a member or members of a racial group or groups of the right to life and liberty of person by inflicting upon the members of a racial group or groups of serious bodily or mental harm, by infringement of their freedom or dignity, or by subjecting them to torture or to cruel, inhuman or degrading treatment or punishment;

-deliberate imposition on a racial group or groups of living conditions calculated to cause its or their physical destruction in whole or in part;

- any legislative measures and other measures calculated to prevent a racial group or groups from participation in the political, social, economic and cultural life of the country and the deliberate creation of conditions preventing the full development of such a group or groups, in particular by denying to members of a racial group or groups basic human rights and freedoms;

- any measures including legislative measures, designed to divide the population along racial lines by the creation of separate reserves and ghettos for the members of a racial group or groups, the prohibition of mixed marriages among members of various racial groups, the expropriation of landed property belonging to a racial group or groups or to members.

There is a connection between the abrogation of Aboriginal rights including selfdetermination as a human right and neocolonialist social dismantling, such as environmental displacement and degradation occurring in many Aboriginal communities. Present day Aboriginal sovereignty issues are precisely about the extent of Aboriginal legal jurisdiction over, and hence access to, land and resources. The question of sovereignty and self-determination embodies the very essence of Aboriginal environmental racism issues. Inequity in the distribution of environmental burdens that First Nations experience often mirror similar inequities in their socioeconomic, political and cultural status and are institutional or systemic in nature. These inequities are falsely 
legitimated by the arrogation of sovereignty by the Canadian state to itself, under current arrangements.

It is important to note that states, according to contemporary international relations and constitutional doctrine themselves have 'derivative rights'. That is to say that the legitimacy of state sovereignty is normatively dependent upon the human right to self-determination. Following from this, citizen rights have been actualized within sovereign states and are regarded by some as citizenship rights (Giddens, 1985). Marshall (1992) identifies three forms of citizenship rights: civil, political and social, while Lister (1997) eludes to a possible fourth: environmental rights. In this context, I do not define 'sovereignty' for Indigenous peoples as 'statehood'. Rather, I define Indigenous 'sovereignty' as including both the right of governance (including derivative rights to development: economic, social, cultural and environmental) and what McClure (1995) defines as positive liberty rights, i.e., autonomy/political rights including legislative powers and a relationship of equality with the Canadian state. How Indigenous peoples conceive of sovereignty, for example, may imply different conceptions of nationhood. These may include differences over aspects of consent, social contract and authority and may not conform to currently held state notions or the dominant political ideology.

\section{Treaties, First Nations Sovereignty and the Canadian State}

Treaties are a form of political recognition indicating a measure of consensual distribution of power. Many argue that the Crown has already acknowledged Indigenous sovereignty and self-governing nation status in entering into 'nation-to-nation treaties' 
(Wildsmith, 1992; RCAP, 1997). Indian and Northern Affairs Canada (INAC) has primary, but not exclusive, responsibility for meeting the federal government's constitutional, treaty, political and legal responsibilities to First Nations, Inuit and Northerners. As such it has fiduciary obligations. This places the trust responsibility for the welfare of 'status' Indians within the realm of INAC, which may devolve responsibilities to Band councils. However, in law, the state has been recognized as the final authority by the courts, not First Nations.

Within the environmental realm, the state must choose to act. As is evident, by the examples I have provided, this rarely occurs. These racist practices influence discriminatory outcomes and are often internalized and systematized within the workings of government, thereby becoming institutional in nature. These racist activities include: 1). physical displacement as a result of development activities without due process or compensation; 2). habitat destruction and degradation; 3). compromised environmental sustainability; and 4). diminished environmental productivity and quality. Such treatment targets First Nations, resulting in cultural, social, economic and environmental instability and is morally and socially reprehensible.

The Crown, in and of itself, has a specific fiduciary obligation to respect, guarantee and protect aboriginal rights (i.e., general doctrine of collective trust) and political authority. From a legal perspective, many contend that the Section 35 of the Constitutional Act of 1982 already protects a core set of Aboriginal interests from unwarranted state intrusion (Slattery, 1992; Wildsmith, 1992; Macklem, 1995; Resnik, 1995; cf. West Coast Fisheries, R. v. Sparrow, 1990). Slattery (1992) suggests that within 
Section 92 the Constitutional Act of 1867, the Aboriginal sphere of influence is coextensive with state authority and has concurrent legislative powers. This interpretation is more in line with policy in the United States, which treats Native Americans as 'domestic dependent nations' (Macklem, 1992/93) or what has been called the 'third domestic sovereign' in Canada (Resnik, 1995).

However, treatied First Nations and in some instances Metis and non-status Indians have progressively seen their sphere of influence on traditional holdings or rights erode with expanding state and capitalist colonization. As the composition of the resident majority shifts to the colonizers, authority progressively swings to those who control legislation. The federal government through transfer agreements, has devolved authority for 'Crown' land to the provinces. By not acknowledging Metis and non-status Indian populations, one could also argue that federal authorities have tried to absolve themselves of responsibilities for these groups. Further provincial governments, through municipal legislation transfer regional autonomy to local governments who treat Aboriginal peoples as citizens, not the bearers of rights.

Thus, Aboriginal rights, as founding nations, are generally ignored. In fact, rarely are Aboriginal rights and authority considered beyond the boundaries of reserve lands. The immediate effect has been to immediately disenfranchise Metis and non-status populations. Furthermore, status Indians under the authority of the Indian Act are represented by the Department of Indian and Northern Affairs Canada (INAC), not themselves, whose mandate does not extend beyond the boundaries of reserve lands. South of $60^{\circ}$ latitude, there are only a select few modern land claims agreements that 
recognize Aboriginal authority. Therefore, Aboriginal interests are only represented offreserve if INAC so chooses, which is rare since the department is not structured to champion Indigenous off-reserve issues in any substantive manner beyond the claims process. Indigenous rights and sovereignty must be constitutionally protected through formal recognition of First Nations as a third-order sovereign. North of $60^{\circ}$ many of these rights have been constitutionally protected through formal land claims processes, thus setting a precedent for affirming First Nation sovereignty.

First Nations maintain that land should not be alienated or preempted until their claims are satisfied. Not unlike treaties, land claims agreements dictate the substance of Crown obligations with respect to Aboriginal lands and authority. As early as 1977, Judge Thomas Berger suggested that settlement of land claims must precede development to ensure social justice for Indigenous peoples. This suggestion has only been entrenched and implemented, primarily, in the three territorial regions that are solely a Federal responsibility.

However, the Canadian and provincial governments' policy is that land claims agreements need not precede resource development. Yet, many of these areas are withdrawn from negotiations and issues of compensation rarely resolved or significantly delayed. Harding (1988) notes that one hindrance to settlement of land allotments in Saskatchewan, is the province's insistence that exploration permits be excluded from land entitlement for treaty obligations and/or land claims. Although it has been acknowledged by the courts that Aboriginal peoples' historic occupation of the land gave rise to legal rights, recent claims legislation, such as the Claim Settlements (Alberta and 
Saskatchewan) Implementation Act, still acknowledges third-party interests which must be resolved to the satisfaction of all parties before lands (two million acres) can be converted to reserve status (Calder et al. v. Attorney General of British Columbia, [1973] S.C.R. 313; Delgamuukw v. British Columbia, [1997] 3 S.C.R. 1010; http://www.aincinac.gc.ca/nr/prs/j-a2002/02119bk_e.html). This legislation does not address the rights of Non-Status Indigenous peoples and Metis, or extraterritorial rights. These legislative processes are indicative of persistent encroachments and appropriations of traditionally held lands and resources.

\section{Resource Development and the Unconstitutional Actions of the Canadian State}

The legitimacy of First Nations sovereignty is grounded both in legal decisions within Canadian courts--even if these courts and governments all too frequently contradict these decisions--and in human rights, especially the right of peoples-nations to self-determination. The matter of sovereignty helps to address environmental racism as expressed in issues of property rights and toxic racism by challenging the legitimacy of the legislative and policy processes that facilitate state and capitalist environmental destruction, devastation and displacement that produces neocolonialism.

At this point, I draw attention to the commonalities of state oppression in resource development, analysed in Chapters Three and Four. Resource development activities without consent and compensation, subjects Indigenous peoples to particularly insidious forms of neocolonialism. Development practices are racist in nature and a violation of Aboriginal fundamental human rights. Many have argued that this wholesale 
development of resources without the expressed consent of Indigenous peoples is unconstitutional (e.g. Berger, 1977; Burrows, 1997; Fry, 1998; Macklem, 1994; RCAP, 1997; Slattery, 1992; Wildsmith, 1992). Development practices breach treaties, bias land claims and self-government negotiations, and fragment Aboriginal societies by eroding economic, territorial and cultural integrity.

For example, in the Montagnais region of Quebec, Indigenous residents have been under siege from resource developers since the $1950 \mathrm{~s} .{ }^{26}$ These activities have been sanctioned by both the Quebec provincial government directly, and the federal government indirectly, through complacency. This area is subject to a claim by Montagnais, who are already seeking restitution and compensation for areas already used for mining, forestry, transportation (railway), hydro development and associated transmission lines, and oil and gas exploration. These areas are deemed unrecoverable by Indigenous residents.

The Montagnais region has been subject to neocolonialism since the 1950s. New developments compound problems, because of cumulative impacts, weakening 'sovereign' claims through further erosion of territorial integrity. As noted above, Environmental Impact Assessments (EIAs) do not recognize Aboriginal authority and treat Aboriginal peoples as stakeholders. By ignoring Aboriginal rights such as legal authority, these assessment processes provide only cursory reviews of Aboriginal issues and claims. The scope and extent of EIAs are subject to the discretion of the Minister of

26. Federal Environmental Assessment Review Office (FEARO), Sainte-Marguerite-3 Hydroelectric Development Project, Supply and Services Canada, Ottawa, Canada, 435 p., June, 1993. 
Environment, who seems oblivious to Constitutional and Charter provisions that supposedly protect Aboriginal rights. Persistently, Environmental Impact Assessment Panels are constrained by the terms of reference set by the Crown (Minister of Environment and responsible authority). But, as early as 1977, Judge Thomas Berger (1977) suggested that settlement of land claims must precede development, to ensure social justice for Indigenous peoples.

To cite another example, in 1971, the Quebec government began to construct the James Bay Hydroelectric Project in an area not yet ceded by either the Cree or Inuit. The land in question had been transferred by the federal government to Quebec under the 1912 Boundary Extension Act with the proviso that the province obtain surrender of native interests. When the province failed to negotiate, the Cree and Inuit filed suit. Both Aboriginal parties, the federal government and Quebec government reached agreement and eventually signed the James Bay and Northern Quebec Agreement in 1975. The James Bay Energy Corporation, James Bay Development Corporation and Hydro Quebec were also party to this agreement. Many find it strange that corporate entities were given standing within this agreement on par with First Nations.

Court decisions also highlight the contradictions of statist ideology with respect to First Nations' rights. Delgamuukw v. British Columbia ([1997] 3 S.C.R. 1010), for instance, held that subject to accommodating Aboriginal peoples' interests, the Crown's infringement of Aboriginal rights could be justified to further certain legislative objectives such as economic development. However, the province had no authority to extinguish Aboriginal rights either under the Constitution Act, 1867 or by virtue of s. 88 
of the Indian Act. The judgment ruled that the federal government must ensure that Aboriginal peoples participate in hearings on resource development activities on traditional lands to ensure 'proper' consultation--some have argued there must be consent--and receive, if necessary, 'fair' compensation. Therefore, the government is obliged to consider the current implications of Aboriginal title in relation to consent and subsequent economic benefits that should accrue to title holders. Even these processes were not equitable in that courts rarely provided guidance. Instead, governments dictated the terms, agenda and scope of negotiations, often favouring provincial and corporate authorities.

In these characteristic cases, the issue of Aboriginal rights and claims and the roles and responsibilities of the signatories, were not clearly addressed (La Duke, 1993). This resulted in little or no progress on the implementation of shared obligations, if identified at all. As a result, the parties negotiated a proposed basis of settlement as a means of addressing outstanding claims and obligations and to provide a platform for negotiations. In Manitoba for instance, four out of five First Nations, excluding Cross Lake, have successfully negotiated settlement agreements, which have been subsequently enacted in both provincial and federal legislation, for example, Bill C-14 (Manitoba Claim Settlements Implementation Act, An Act Respecting an Agreement with the Norway House Cree Nation for the Settlement of Matters Arising from the Flooding of Land, and Respecting the Establishment of Certain Reserves in the Province of Manitoba, 48-49 Elizabeth II, 1999-2000). These agreements address the rights of treatied Aboriginal peoples but currently ignore the rights of non-status Indians and Metis. 
An ancillary note which may be of particular interest to readers, is that these agreements did not consider the issues of the right-of-way and associated environmental impacts of hydro corridors to southern markets including associated electromagnetic effects. The Lac Courte Oreilles Band of Lake Superior Chippewa contend that exposure of band members to extremely low frequencies near the east end of their reservation near Clam Lake may account for inordinately high cancer rates and oppose a second transmission line, the Arrowhead Weston project, on the west side, in which, Manitoba Hydro plays a part. They perceive this infringement on their tribal sovereignty and cultural and environmental rights as 'environmental racism' (Isham, 2000).

Again, I must stress the commonality of these events. Very few development activities - for example, agricultural practices - come under close scrutiny in Canada or are subject to environmental assessment processes. These inter-jurisdictional, transboundary activities often have significant long-term cumulative environmental effects, such as, the drawing down of the water table through irrigation and/or the contamination of the water supply and air shed. These cumulative environmental effects intrude on Aboriginal sovereignty and environmental human rights. Even where treaties or agreements exist, provisions have not been respected (cf. Dickason, 1997; RCAP, 1997). Examples include Serpent River First Nations, Robinson Huron Treaty and Dominique-Janine Extension ${ }^{27}$, Treaty 10). They may also be subjected to extensive

27 . Federal Environmental Assessment Review Office (FEARO), Dominique-Janine Extension, McClean Lake Project, and Midwest Joint Venture, Supply and Services Canada, Ottawa, Canada, 66 p., October, 1993. (Wollaston Lake); Federal Environmental Assessment Review Office (FEARO), Rabbit Lake Uranium Mining, Supply and Services Canada, Ottawa, Canada, 47 p., November, 1993; Canadian Environmental Assessment Agency (CEAA), McArthur River Uranium Mine Project, Supply and Services Canada, Ottawa, Canada, 75 p., February, 1997; Canadian Environmental Assessment Agency (CEAA), 
delays in implementation without compensation as one finds with the Manitoba Northern Flood Agreement. ${ }^{28}$

Each of the cases discussed herein demonstrate that Indigenous peoples are cast in the role of passive objects, those acted upon, rather than as active political agents. Burrows's (1997) Georgian Bay study provides further evidence that federal and provincial structures often eclipse First Nations' sphere of influence resulting in a constriction of political space. Aboriginal peoples have become submerged and invisible in their own land with states substituting enforced dependency for self-determination. The cases discussed and analysed in Chapter Three and Four, forcefully indicate that the current "legislative" process, e.g., those constituted through the CEAA, is normatively bankrupt and contravenes both legal historical precedents of Canadian courts and the International Convention on Human Rights. Given this circumstance, there is every reason for First Nations in Canada to redress the environmental racism and consequent neocolonialist effects of displacement, destruction and devastation by asserting their sovereignty.

In this light, it is necessary to acknowledge some degree of Aboriginal sovereignty, or what Connolly (1995) refers to as "the reterritorialization of First Nations and the 'deterritorialization of state'. Connolly's (1995) notion of 'reterritorialization' speaks to the state both acknowledging and providing formal legal recognition of

Midwest Uranium Mine Project, Cigar Lake Uranium Mine Project and Cumulative Observations, Supply and Services Canada, Ottawa, Canada, 161 p., November, 1997.

28. Manitoba Northern Flood Agreement, (December, 1977). 
Aboriginal 'sovereign' authority. These changes must acknowledge Aboriginal rights to self-determination and authority, including the right of self-governance. This partial devolution or sharing of sovereign authority or control would empower First Nations. Deterritorialization requires states to acknowledge Aboriginal rights to self-determination and authority thus relinquishing a degree of 'sovereign' control (cf. Santo,1995).

\section{Sovereignty as a Potential Strategy}

All too often, there is a disinclination by states to question existing sociopolitical and economic arrangements that create inequality. Rather, the political response in Canada to social inequities, including those of an environmental nature, is to treat the outcome, rather than target the cause. This policy relies on a distributive justice or quasiwelfare state model (Foster, 1993). This model places Aboriginals in a relation of dependency. But, from the perspective of environmental racism discourse, an allencompassing justice system includes aspects of sovereignty, offering First Nations freedom of choice and meaningful social change. A degree of sovereignty is ostensibly progressive, in that it promotes process equity over the previous, largely exclusionary, static, outcome-equity model.

The state remains the central structure regulating access to social distribution (Soysal, 1995). Generally, states play (and played) a significant role in the brutalization of its Indigenous 'citizenry', either through colonialism and neocolonialism, and/or by allowing or condoning similar actions by others (Kastrup, 1997). This is clearly the practice within Canada where past and present political, legal, economic and human 
rights regimes did not protect Aboriginal interests with any certainty. Rather, the normative and political underpinnings of Canadian federalism have been antagonistic since constructing Aboriginals as 'racial others'. This suggests that Canadian democratic ideals with respect to First Nations can be easily construed as racist in nature (Connolly, 1995; Santos, 1995; Tully, 1995). For example, development activities continue to assume that Crown land, with residual Aboriginal rights, is vacant and is in sole possession of the provinces.

By overlooking Aboriginal rights-in-land, the provinces and hence the state, are disproportionately targeting Indigenous peoples and breaching their fundamental human rights. Referring to the definition of environmental racism and the convention on human rights, one must concede that this is strong evidence of racism. Aboriginal nations did not cede sovereign rights during treaty negotiations. Rather, links between First Nations and the Crown were broadly confederal. Thus, Indigenous peoples, represent 'a competing nationalism posited in a variety of forms within the boundaries of the state, challenging two fundamental statist notions: that of an exclusive territorial sovereignty and the notion of a unified 'nationality' administered by governmental organs' (Falk, 1988). The founding of modern day constitutions and political and legal institutions were subsequently used to define sovereignty and in so doing, to dispossessed, suppressed and denied Aboriginal nations equal status (Tully, 1995). They are thus morally and ethically bankrupt in historical justification (Macklem, 1994). This violation of Indigenous fundamental human rights serves to propagate social disorder and stifle democratic processes. Further, this denial of rights can also be construed as a denial of justice and is 
inconsistent with the general principles of legal traditions such as respect of promise (contractual) and security of property.

However, only in certain cases do forms of resistance take on a political character and become struggles directed toward putting an end to these relations of subordination and oppression (Laclau and Mouffe, 1985). Those issues receiving extensive public and international scrutiny are often brought to the forefront by activists such as human rights organizations, academics, First Nation, themselves, international bodies, etc. (cf. Jhappan, 1992). Oppression as defined by Laclau and Mouffe (1985) are those relations that have transformed themselves into sites of antagonism, relations of domination, that are considered to be illegitimate by the judgment of an agent external to them, e.g., those acting on the basis of international human rights. Most often, it is not simply a question of difference but one about state politics, and the uneven distribution of resources and political and economic power. Ultimately, at the core of this polarization, are the politics of natural resource use since Aboriginal laws, societies and cultures are tied to the land. Assertions and affirmations of First Nations sovereignty may potentially strengthen their position in struggles with the Canadian state.

Only through the repatriation of sovereignty rights including derivative rights, such as environmental human rights, and positive liberty rights such as political rights or democratic empowerment, can First Nations truly experience meaningful self-direction and social equality. This notion of sovereignty is more protean and inclusive and speaks to substantive entitlements and responsibilities. This in turn may promote process equity and emancipation from the hegemonic development models used by corporations and 
nation-states for unfettered access to Indigenous lands and resources (Santos, 1995). Justice, for First Nations, requires a more open, communicative and participatory political process that is transparent, democratic and inclusive. However, this is not likely to happen in a political vacuum since there is a tendency for states to attempt to increase their control of power relations. Environmental racism discourse offers another means to challenge state constitutional, juridical and statutory authority by subjecting states' 'democratic' practices to both internal and external scrutiny. This new perspective not only strengthens Aboriginal 'sovereign' claims but highlights the need for formal constitutional recognition of Indigenous peoples' third-order sovereign rights, facilitating democracy and social justice. However, without Aboriginal reterritorialization, repatriation or reinstatement of sovereignty, instrumental powers or control, over critical lands and resources, the democratization of society is impossible since Indigenous peoples are excluded (Arato and Cohen, 1984).

I do not presume to know exactly what Indigenous peoples want or will accept as their 'sovereign' rights. Strategies might involve constitutional negotiations or new elaborate and systematic legal plans of action using existing statutes, the constitution or judicial doctrines to change the existing legal superstructure (Swartz, 1994). This implies that legal discourse needs to recoup its emancipatory potential. However, as Tully (1995) notes, modern constitutionalism in Canada has been superimposed on First Nations. First Nations are already constitutional entities (e.g. Section 25) but have no instrumental powers. New constitutional provisions must recognize Indigenous sovereignty by affirming, delimiting and protecting their autonomy and cultural identity (Slattery, 1992). 
Resnik (1995) proposes recognition of a 'third domestic sovereign' outside of parliamentary and provincial or territorial jurisdiction or purview.

Such an arrangement would be similar, but not identical, to what is referred to as 'asymmetrical federalism'. Asymmetrical federalism is already constitutionally recognized and used to accommodate Quebec, and French language and cultural rights nationally. However, RCAP (1997) supports a broader concept of Indigenous peoples inalienable right to self-determination and 'sovereignty', beyond culture and language. They see this as embodying a more democratic system of decentralized governance that offers First Nations both derivative rights to development, be it economic, social, cultural or environmental, and positive liberty rights, including some degree of autonomy, political rights, legislative powers and a relationship of equality. This proposal qualifies sovereignty and provides for increased consent, a social contract and authority. Unlike the American system of domestic dependent nations (Macklem, 1992/93), in theory, this model would extent instrumental powers beyond reserves or secured lands and would include co-management of un-secured hearth areas of cultural, environmental, social and economic significance. As such, it would be more of a confederal arrangement.

\section{Conclusion}

Through the environmental racism analytic developed in this thesis, racist practices toward Indigenous peoples are further exposed to public and international scrutiny, and the Canadian state challenged to comply with international human rights and environmental standards. Actionable rights of this sort are a means to empower 
Indigenous peoples by offering new forms of cultural and political recognition and dialogue that is inclusive of their environment. This provides a basis for transforming First Nations from passive objects to active subjects. By increasing political equality through actionable rights, one provides a degree of social, environmental and economic equality (Young, 1990).

Environmental racism discourse challenges the 'over-coding' or 'chauvinistic nationalism' of state oppression of First Nations (Santos, 1995). State over-coding refers to the confinement of democracy to the governmental institutions of the territorial state (Connolly, 1995). This over-coding, in effect condones state violence against Indigenous peoples with competing claims of nationalisms. This provides another avenue of resistance which takes on a political character directed toward putting an end to these relations of subordination and oppression. For self-determination and social justice to become a reality for First Nations, unencumbered access and control over traditional lands and resources is a prerequisite. The current Canadian federalist system and perhaps Constitutional law, have privileged provincial and corporate entities to the detriment of Indigenous Nations. This leads me to conclude that without reterritorialization, repatriation or reinstatement of sovereignty, Aboriginal societies will continue to suffer.

Social justice must include institutional rights as a means for First Nations to assert some degree of control over the form, content and direction of their distinct, individual and collective identities to be meaningful, covering education, information, culture, religion, health, housing, social welfare, traditional and economic activities, land and resource administration and the environment. Assertions and affirmations of First 
Nations sovereignty, as derived from the human right of collectivities to self-

determination, provides a strong normative basis for making social justice for them a substantive reality. 


\section{Chapter 6: Conclusion}

The expanded 'environmental racism' analytic developed in this thesis has been employed to more fully divulge and expose the extent, urgency and legitimacy of Aboriginal environmental justice claims in Canada. The concept of environmental racism has been expanded beyond the focus on civil rights and environmental justice. I have done so by incorporating the two key notions of human rights namely, the rights to security of person and self-determination. Environmental racism, as newly defined, reveals that Indigenous peoples are subject to neocolonialist oppression by the Canadian state. This neocolonialism is characterized by violence through environmental displacement and degradation in contrast to 'colonialism' that did so through direct violence and coercion. The activities of the environmentally racist state undermine the biophysical and sociological sustainability of Indigenous peoples and hence is in breach of their human rights. As such, I have argued that an effective environmental racism analytic, pertinent to Indigenous peoples, requires a framework adequate to incorporating a broader view of the linkages between economic, environmental, political and social forces, including human rights, determining discriminatory outcomes.

My analysis focussed on three major environmental racist practices or burdens: systemic racism in legislation and process, toxic racism and sovereignty. These elements are unique to Indigenous claims of environmental racism. Neocolonialism, and its precursor colonialism, have been shown to be salient to past and present practices of the Canadian state, thus eroding Aboriginal lands and resources. These are the basis of 
Indigenous economic, environmental, cultural and social self-sufficiency. Evidence of the denial of basic human rights within existing state structures and institutions, especially as concerns the Canadian Environmental Assessment Agency, were provided as proof of systemic environmental racism.

Observable disparate environmental impacts--or macro-impacts--borne disproportionately by Indigenous peoples, have been analysed and elucidated. Toxic racism is heightened for First Nations, in particular, because they are primary resource users. The immense geography of scale of toxic racism impairs critical ecosystem components and environmental health, as well as Indigenous social, cultural and economic well-being. Toxic racism was analysed by using four distinct categories: contamination of the food chain; ecosystem health; noise pollution; and electromagnetic radiation. Similarly, I have elucidated the connection between the abrogation of the Aboriginal right to self-determination or actionable rights, and the social, economic, environmental and cultural dismantling they disproportionately bear.

Environmental racism discourse helps broaden state environmental politics by delineating the structural and institutional nature of environmental racism, exposing hegemonic state practices and beliefs, and by highlighting the cultural and racial bigotry inherent within our constitution and political and legal institutions. This, in turn, challenges or questions the moral rectitude of equitable political rights within 'democratic' states such as Canada, and offers another means of confronting human rights abuses within the state. Environmental racism discourse can potentially function as a catalyst for creative political engagement by challenging a state's monopoly over the 
allegiances, identifications and energies of its Indigenous citizenry. It does this by ensuring that native rights and social justice are waged on parallel fronts while providing a locus for fusing Aboriginal environmental concerns. Thus, the environmental racism analytic provides both a critical discourse, unmasking the structural and institutional nature of racism, and a creative discourse demanding the democratization of state and reterritorialization, both politically and territorially. This requires an arrangement inclusive of First Nations, affirming their human right to self-determination.

Demonstrating the multifaceted character of environmental racism, implies an obvious need to broaden and decolonize environmental justice theory and law. Environmental racism not only injures its victims but often violates their fundamental human rights. This supports Williams's (1994) contention that "protecting environmental values is anterior to and a prerequisite for protecting all our other core human rights". Environmental racism discourse provides a normative justification for fundamental social and environmental change by unmasking exclusionary processes and normative judgments that influence racially meaningful social structures. This may stimulate a renewed political and cultural dialogue and innovative practices that do not repeat the injustices of the past.

In sum, the environmental racism analytic legitimately demonstrates the moral obligations of states to:

- restrain development when it is proven that discriminatory environmental and social outcomes will create environmental victims whether through a lack of knowledge or ignorance, or by its own volition or predatory behaviors; 
- regulate actions with socio-environmental consequences;

- provide adequate restitution or remediation even if victimization occurred in previous generations;

- engage in preventative and rehabilitative measures;

- develop new national environmental juridical concepts (Northern, 1997 suggests strengthening tort law) or doctrines;

- enact and enforce new environmental and social standards of conduct for

federal, provincial and corporate bodies; and

- articulate, measure and assert national standards for social performance including responsibility and accountability.

Responsibility without accountability is meaningless. Experience, however, suggests that both the potential and the incentive for learning are greatest when those making the resource-management decisions are the ones experiencing the results of those decisions. 


\section{Bibliography}

Arto, A. and J.L. Cohen, "Social Movements, Civil Society and the Problem of Sovereignty" (1984) 4 Praxis International 266.

Attfield, R., "Environmental Ethics and Intergenerational Equity" (1998) 41 Inquiry 207.

Baldwin, R.T. and S. Preston-Martin, "Epidemiology of Brain Tumors in Childhood: A Review" (2004) 199 Toxicology and Applied Pharmacology 118.

Balibar, E., "Es Gibt Keinen Staat in Europa: Racism and Politics in Europe Today" (1991) 186 New Left Review 5.

Bartelson, J., A Genealogy of Sovereignty (Cambridge: Cambridge University Press 1995) 49-52.

Beck, U., "From Industrial Society to the Risk Society: Questions of Survival, Social Structure and Ecological Enlightenment" (1992) 9 Theory, Culture \& Society 97.

Berger, T.R., Northern Frontier Northern Homeland: The Report of the Mackenzie Valley Pipeline Inquiry, Vol. 2 (Ottawa: Supply and Services Canada 1977).

Berman, D., "Saskatchewan Citizens Disillusioned by Uranium Mine Approvals" (1994) 20 Alternatives 6.

Blais, L.E., "Environmental Racism Reconsidered" (1996) 75 North Carolina Law Review 75.

Braune, B.M. and M. Simon, "Trace Elements and Halogenated Organic Compounds in Canadian Arctic Seabirds" (2004) 48 Marine Pollution Bulletin 986.

Bryant, B., "Issues and Potential Policies and Solutions For Environmental Justice: An Overview" in B. Bryant (ed) Environmental Justice: Issues, Policies and Solutions (Washington: Island Press 1995) 8-34.

Bullard, R.D., "Solid Waste Sites and the Black Houston Community" (1983) 53 Sociological Inquiry, 273.

Bullard, R.D., "The Threat of Environmental Racism" (1993) 7 Natural Resources and Environment, 23.

Bullard, R.D., "Overcoming Racism in Environmental Decisionmaking" (1994) 36 Environment 10. 
Burke, L.M., "Race and Environmental Equity: A Geographic Analysis in Los Angeles" (1993) 3 Geo Info Systems 44.

Burrows, J., "Living Between Water and Rocks: First Nations" (1997) 47 Environmental Planning and Democracy 417.

Buttel, F.H. and W.L. Flinn, "Social Class and Mass Environmental Beliefs: A Consideration" (1978) 10 Environment and Behaviour 433.

Cameron, K. and G. White, Northern Governments in Transition (Montreal: The Institute for Research on Public Policy 1995).

Camilleri, J.A. and J. Falk "Sovereignty in Theory and Practice", in The End of Sovereignty: The Politics of a Shrinking and Fragmenting World (Aldershot: Edward Elgar 1992) 11-43.

Capek, S.M., "The 'Environmental Justice' Frame: A Conceptual Discussion and an Application”, (1993) 40 Social Problems 5.

Carpenter, D.O., "Human Health Effects of Environmental Pollutants: New Insights" (1998) 53 Environmental Monitoring and Assessment 245.

Chen, W., J. Waters, K. Grimsrud, A. Schecter, T.L. Guidotti, D. Schopflocher, D.G. Muir and S. Gabos, "Development of Food Consumption Advisories Following Accidental Release of PCBs, PCDDs and PCDFs From a Special Waste Treatment Centre Incident" (1998) 39 Organohalogen Compounds 181.

Cole, L.W., "Empowerment as the Key to Environmental Poverty Law" (1992) 19 Ecology Law Quarterly 619.

Collins, R.W., "Review of the Legal Literature on Environmental Racism, Environmental Equity and Environmental Justice" (1994) 9 Journal of Environmental Law and Litigation 121.

Connolly, W.E., "Introduction, Democracy and Territoriality and Tocqueville, Religiosity and Pluralization", in The Ethos of Pluralization (Minneapolis: University of Minnesota Press 1995) xi, 135-198.

Cutter, S.L., D. Holm and L. Clark, "The Role of Geographic Scale in Monitoring Environmental Justice" (1996) 16 Risk Analysis 517.

Davidson, D.J. and W.R. Freudenburg, "Gender and Environmental Risk Concerns: A Review and Analysis of Available Research" (1996) 28 Environment and Behaviour 302. 
Delicaet, A., "The New Environmental Assessment Act: A Comparison With the Environmental Assessment Review Process" (1995) 15 Impact Assessment Review 497.

Delora, V., "Laws Founded in Justice and Humanity: Reflections on the Content and Character of Federal Indian Law" (1989) 31 Arizona Law Review 203.

Dembo, D., W. Morehouse and L. Wykle, "Toward Corporate Social Accountability: Lessons From the Union Carbide Story" in Abuse of Power: Social Performance of Multinational Corporations. The Case of Union Carbide (New York: New Horizon Press 1990) 131-157.

Di Chiro, G. "Nature as Community: The Convergence of Environment and Social Justice" in W. Cronon (ed.) Uncommon Ground: Toward Reinventing Nature (W.W. Norton \& Company 1995) 298-320.

Dickason, O.P., Canada's First Nations (Toronto: Oxford University Press 1997).

Dudka, S. and W.P. Miller, "Accumulation of Potentially Toxic Elements in Plants and Their Transfer to Human Food Chain" (1999) 34B Journal of Environmental Science and Health 681.

Falk, R., "The Rights of Peoples (In Particular Indigenous Peoples)", in J. Crawford (ed) The Rights of Peoples (Oxford: Clarendon Press 1988) 17-37.

Falk, R., "Revisiting the Right of Self-Determination", in R. Falk (ed) Human Rights Horizons: The Pursuit of Justice in a Globalizing World (New York: Routledge 2000) 97-125.

Fields, B.J., "Slavery, Race and Ideology in the United States of America" (1990) 181 New Left Review 95.

Fisher, M.,"Environmental Racism Claims Brought Under Title VI of the Civil Rights Act", (1995) 25 Environmental Law 285.

Foster S., "Race(ial) Matters: The Quest For Environmental Justice" (1993) 20 Ecology Law Journal 721.

Frankenfeld, P.J., "Technological Citizenship: A Normative Framework For Risk Studies" (1992) 17 Science, Technology \& Human Values 459.

Freeman, M., "Are There Collective Human Rights" (1995) 43 Political Studies 25.

Fry, P., "A Social Biosphere: Environmental Impact Assessment, the Innu and Their 
Environment", (1998) 56 University of Toronto Faculty of Law Review 177.

Gamble, R.L., "Native Harvest of Wildlife in the Keewatin Region, Northwest Territories for the Period October 1985 to March 1986 and a Summary for the Entire Period of the Harvest Study from October 1981 to March 1986", (1988) 688 Canadian Data Report of Fisheries and Aquatic Sciences 85 p.

Gareis-Smith, D., "Environmental Racism: The Failure of Equal Protection to Provide a Judicial Remedy and the Potential of Title VI of the 1964 Civil Rights Act" (1994) 13 Temple Environmental Law and Technology Journal 57.

Giddens, A., The Nation-State and Violence: Volume Two of a Contemporary Critique of Historical Materialism (Berkeley: University of California Press 1985) 198-221.

Goldman, B.A., Discounting Human Lives: Uranium and Global Equity, PhD Thesis, Robert F. Wagner Graduate School of Public Service (New York: New York University 1993).

Goldstick, M., Wollaston: People Resisting Genocide, (Montreal: Black Rose Books 1987).

Goldtooth, T.B.K.,"Indigenous Nations: Summary of Sovereignty and Its Implications For Environmental Protection" in B. Bryant (ed.) Environmental Justice: Issues, Policies and Solutions (Washington: Island Press 1995) 138-148.

Guay, L., "Social and Political Factors of Environmental Protection in Canada", in M.D. Mehta and E. Ouellet (eds,) Environmental Sociology: Theory and Practice, (North York: Captus Press 1995) 277-295.

Guidotti, T.L., S. Gabos, D. Schopflocher, J. Waters, K. Grimsrud, D.G. Muir, D. Schindler, K.L. Froese, J.M. Blais, S. Ramamoorthy, S. Chan and W. Chen, "Health Impact Assessment of PCBs, PCDDs and PCDFs in Relation to a Special Waste Treatment Centre Incident in Alberta, Canada" (1998) 39 Organohalogen Compounds 165.

Habash, R.W.Y., L.M. Brodsky, W. Leiss, D. Krewski and M. Repacholi, "Health Risks of Electromagnetic Fields: Part 1.Evaluation and Assessment of Electri-Magnetic Fields" (2003) 31 Critical Reviews in Biomedical Engineering 141.

Harding, J., "Aboriginal Rights and Government Wrongs: Uranium Mining and Neocolonialism in Northern Saskatchewan", in In the Public Interest, Working Paper No. 1 (Regina: Prairie Justice Research 1988). 
Held, D., "Democracy, the Nation-State and the Global System", in S. Hall and M. Jacques (eds) New Times: The Changing Face of Politics in the 1990s (New York: Verso 1989) 189-204.

Hirst, P.Q. and G. Thompson, "Globalization and the Future of the Nation State" (1995) 24 Economy and Society 408.

Hornstein, D.T. "Reclaiming Environmental Law: A Normative Critique of Comparative Risk Analysis" (1992) 92 Columbia Law Review 562.

Inter-Church Uranium Committee and the Northern Native Rights Committee (ICUC \& NNRC), "Economic Options For Northern Saskatchewan" in Report of the Economic Options For Northern Saskatchewan Conference, (Saskatoon: On Sky 1984).

Isham, Jr., M.J., LCO Vice Chairman Mic Isham Says Gaawiin-No to the Proposed Transmission Line, December 6, 2000 http://www.glifwc.org.

Jeffreys, K., “Environmental Racism: A Skeptics View” (1994) 9 St John's Journal of Legal Commentary 677.

Jhappan, C.R., "Global Community?: Supranational Strategies of Canada's Aboriginal Peoples" (1992) 3 Journal of Indigenous Studies 59.

Johnson, B.L., H.E. Hicks, W. Cibulas, O. Faroon, A.E. Ashizawa, C.T. De Rosa, V.J. Cogliano and M. Clark, Public Health Implications of Exposure to Polychlorinated Biphenyls (PCBs) (Atlanta: United States Federal Agency For Toxic Substances and Disease Registry 1999) 40.

Johnson, B.R., "Environmental Degradation and Human Rights Abuse" in Who Pays the Price? The Sociocultural Context of Environmental Crisis (Washington: Island Press 1994) 7-15.

Kapashesit, R. and M. Klippenstein, "Aboriginal Group Rights and Environmental Protection" (1991) 36 McGill Law Journal 923.

Kastrup, J.P., "The Internationalization of Indigenous Rights From the Environmental and Human Rights Perspective" (1997) 32 Texas International Law Journal 97.

Kuehn, R.R., "A Taxonomy of Environmental Justice" (2000) 30 Environmental Law Reporter 10681.

Kymlicka, W., "Three Forms of Group-Differentiated Citizenship in Canada", in S. Benhabib (ed.) Democracy and Difference: Contesting the Boundaries of the Political 
(Princeton: Princeton University Press 1996) 153-170.

La Duke, W., "A Society Based on Conquest Cannot be Sustained: Native Peoples and the Environmental Crisis", in R. Hofrichter (ed.) Toxic Struggles: The Theory and Practice of Environmental Justice (Gabriola Island: New Society Publishers 1993) 98106.

Laclau, E. and C. Mouffe, "Hegemony and Radical Democracy", in Hegemony and Social Strategy (London: Verso 1985) 149-194.

Larrain, J., "Ideology, Reason and the Construction of the Other", in Ideology and Cultural Identity: Modernity and the Third World Presence (Cambridge 1994) 6-32. Journal 173.

Lister, R., Citizenship: Feminist Perspective (New York: New York University Press 1997).

Macklem, P., "Distributing Sovereignty: Indian Nations and Equality of Peoples" (1992/93) 45 Stanford Law Review 1311.

Macklem, P., "Normative Dimensions of the Right of Aboriginal Self Government", in Aboriginal Self Government: Legal and Constitutional Issues (Ottawa: Supply and Services Canada 1994) 1-54.

Macklem, P., "Normative Dimensions of an Aboriginal Right of Self-Government" (1995) 21 Queen"s Law Journal 173.

Maggio, G.F., "Inter/Intra-Generational Equity: Current Applications Under International Law For Promoting the Sustainable Development of Natural Resources" (1997) 4 Buffalo Environmental Law Journal 161.

Mallory, M.L., B.M. Braune, M. Wayland and K.G. Drouillard, "Persistent Organic Pollutants in Marine Birds, Arctic Hare and Ringed Seals Near Qikiqtarjuaq, Nunavut, Canada" (2005) 50 Marine Pollution Bulletin 95-104.

Marshall, T.H., "Citizenship and Social Class", in T.H. Marshall and Tom Bottomore (eds) Citizenship and Social Class (London: Pluto 1992) 3-51.

McClure, K.M., "Taking Liberties in Foucault's Triangle: Sovereignty, Discipline, Governmentality and the Subject of Rights", in A. Sarat and T.R. Kearns (eds.) Identities, Politics and Rights (Ann Arbor: The University of Michigan Press 1995) 149-192.

McMaster, R.B., H. Leitner and E. Sheppard, "GIS-Based Environmental Equity and Risk 
Assessment: Methodological Problems and Perspective" (1997) 24 Cartography and Geographic Information Systems 172.

Mehta, M.D.,"Environmental Risk: A Macrosociological Perspective", in M.D. Mehta and E. Ouellet (eds.) Environmental Sociology: Theory and Practice (North York: Captus Press 1995) 185-202.

Muldrew, F.,"Indigenous Women Dump on Nuclear Waste Storage" (1996) 10 Herizons 8.

Murphy, R., "Environmental Classes and Environmental Conflict" in Rationality and Nature: A Sociological Inquiry Into a Changing Relationship, (Boulder: Westview Press 1994) 163-190.

Nelkin, D., "Native Americans and Nuclear Power" (1981) 6 Science, Technology and Human Values 2.

Nielsen, J. McCarl, Feminist Research Methods: Exemplary Readings in the Social Sciences, (Boulder, Colorado: Westview Press 1990).

Northern, K.S., "Battery and Beyond: A Tort Law Response to Environmental Racism" (1997) 21 William and Mary Environmental Law and Policy Review 485.

Northridge, M.E. and P.M. Sheppard, "Environmental Racism and Public Health" (1997) 87 The American Journal of Public Health 730.

O'Connor, J., "The Promise of Environmental Democracy", in R. Hofrichter (ed.) Toxic Struggles: The Theory and Practice of Environmental Justice (Gabriola Island: New Society Publishers 1993) 47-57.

Orton, D., “Deep Left Dilemmas" (1996) 30 Canadian Dimensions 26.

Parenteau, B.,, "Care, Control and Supervision: Native People in the Canadian Atlantic Salmon Fishery, 1867-1900" (1998) 79 The Canadian Historical Review 1.

Penz, P., "Environmental Victims and State Sovereignty" (1996) 23 Social Justice 41.

Perera, F.P., W. Jedrychowski,V. Rauh and R.M. Whyatt, "Molecular Epidemiologic Research on the Effects of Environmental Pollutants on the Fetus" (1999) 107 Environmental Health Perspectives 451.

Peters, E., "Geographies of Aboriginal People in Canada" (2001) 45 The Canadian Geographer 138. 
Pinderhughes, R., "The Impact of Race on Environmental Quality: An Empirical and Theoretical Discussion" (1996) 39 Sociological Perspectives 231.

Popovic, N.A.F., "Pursuing Environmental Justice With International Human Rights and State Constitutions" (1996) 15 Stanford Environmental Law Journal 339.

Pulido, L., "A Critical Review of the Methodology of Environmental Racism Research" (1996) 28 Antipode 142.

Redpole, P., "One Tribe's Development of a Commercial Waste Facility in the Wake of Environmental Racism" (1992) 1 Greater North Central Natural Resources Journal 209.

Rees, J., "Equity and Environmental Policy" (1991) 76 Geography 292.

Resnik, J., "Multiple Sovereignties: Indian Tribes, States and the Federal Government" (1995) 79 Judicature 118.

Rex, J., "Race and Ethnicity" in Concepts in the Social Science (Buckingham: Open University Press 1986) 148.

Richardson, M.J., J. Sherman and M. Gismondi, Winning Back the Words: Confronting Experts in an Environmental Public Hearing (Toronto Garamond Press 1993) 185.

Royal Commission on Aboriginal Peoples (RCAP), For Seven Generations: An Information Legacy of the Royal Commission on Aboriginal Peoples, ISBN 0-9698178-19, (Ottawa: Libraxis Inc.1997).

Sachs, A., "Upholding Human Rights and Environmental Justice" (1996) 56 The Humanist 5.

Sadar, M.H. and W.J. Stolte, "An Overview of the Canadian Experience in Environmental Impact Assessment (EIA)" (1996) 14 Impact Assessment 215.

Salazar, D.J., "Environmental Justice: Grassroots Activists Push the Frontiers of Forestry and Politics", in William P. Thompson Memorial Lecture Series, No. XX, (Flagstaff: Northern Arizona University 1996) 4-19.

Santos, B., "Globalization, Nation-States and the Legal Field: From Legal Diaspora to Legal Ecumenism?", in Towards a New Common Sense: Law, Science and Politics in the Paradigmatic Transition (London: Routledge 1995) 250-377.

Seth, R. and D. Mackay, "Do Toxic Chemical Spills Contribute Significantly to Human and Environmental Exposure in Canada?" (1999) 24 Spill Technology Newsletter 1. 
Shanklin, C., "Pathfinder: Environmental Justice" (1997) XXIV Ecology Law Quarterly 333.

Sherman, J. and M. Gismondi, "Jock Talk, Goldfish, Horse Logging and Star Wars" (1997) 23 Alternatives Journal 14.

Shkilnyk, A.M., A Poison Stronger Than Love: The Destruction of an Ojibwa Community (New Haven: Yale University Press 1995).

Slattery, B., "First Nations and the Constitution: A Question of Trust" (1992) 71 Canadian Bar Review 261.

Smith, D., "The Emergence of 'Eskimo Status': An Examination of the Eskimo Disk List System and Its Social Consequences", in Anthropology, Public Policy and Native Peoples in Canada (Montreal: McGill-Queens University Press 1993) 41-74.

Soysal, Y.N., "Towards a Postnational Model of Membership" in Limits of Citizenship: Migrants and Postnational Membership in Europe, (Chicago: The University of Chicago Press 1995) 137-162.

Spaulding, R., "Peoples as National Minorities: A Review of Will Kymlicka's Arguments For Aboriginal Rights From a Self-Determination Perspective" (1997) 35 University of Toronto Law Journal 35.

Stephens, S., "Reflections on Environmental Justice: Children as Victims and Actors" (1996) 23 Social Justice 62.

Swartz, A., "Environmental Justice: A Survey of the Ailments of Environmental Racism" (1994) 2 Howard Scroll: The Social Justice Review 35.

Taliman, V., "The Toxic Waste of Indian Lives" (1992) 40 Covertaction 16.

Tarlock, A.D., "Exclusive Sovereignty Versus Sustainable Development of a Shared Resource: The Dilemma of Latin America" (1997) 32 Texas International Law Journal 37.

Taylor, Andrew, "Governance", in Georgina Blakely and Valerie Bryson (eds.) Contemporary Political Concepts (Virginia: Pluto Press 2002) 35-53.

Torres, G., "Race, Class and Environmental Regulations" (1992) 63 University of Colorado Law Review 839.

Tribes, L.H., "The Curvature of Constitutional Space: What Lawyers Can Learn From 
Modern Physics", (1989) 103 Harvard Law Review 1.

Tully, J. Strange Multiplicity: Constitutionalism in an Age of Diversity (Cambridge: Cambridge University Press 1995) 253.

Vaughan, E. and Nordenstam, B., "The Perception of Environmental Risks Among Ethnically Diverse Groups" (1991) 22 Journal of Cross-Cultural Psychology 29.

Walker, G., "Environmental Justice and the Politics of Risk" (1998) 67 Town and Country Planning 358.

Westra, L., "Development and Environmental Racism: The Case of Ken Saro-Wiwa and the Ogoni" (1998) 6 Race, Gender and Class 152.

Wheatley, B. and S. Paradis, "Balancing Human Exposure, Risk and Reality: Questions Raised by the Canadian Aboriginal Methylmercury Program" (1996) 17 NeuroToxicology 241.

Wheatley, B., S. Paradis, M. Lassonde, M.-F. Giguere and S. Tanguay, "Exposure Patterns and Long Term Sequelae on Adults and Children in Two Canadian Indigenous Communities Exposed to Methylmercury" (1997) 97 Water, Air and Soil Pollution 63.

Wheatley, M.A., "The Social and Cultural Effects of Mercury on Aboriginal Peoples" (1994) 14 NeuroToxicology 972.

Wheatley, M.A., "Social and Cultural Impacts of Mercury Pollution on Aboriginal Peoples in Canada" (1997) 97 Water, Air and Soil Pollution 85.

Wildsmith, B.H., "Treaty Responsibilities: A Co-Relational Model" (1992) Special Edition University of British Columbia Law Review 324.

Williams, R.A., Jr., "Large Binocular Telescopes, Red Squirrel Pinatas and Apache Sacred Mountains: Decolonizing Environmental Law in a Multicultural World" (1994) 96 West Virginia Law Review 1133.

Yamamoto, E.K. and J.-L.W. Lyman, "Racializing Environmental Justice" (2001) 72 University of Colorado Law Review 311.

Young, I.M., "Together in Difference: Transforming the Logic of Group Political Conflict", in Principled Positions: Postmodernism and the Recovery of Valve, (London: Lawrence and Wishart 1993) 121-150. 